\title{
Summary of the
}

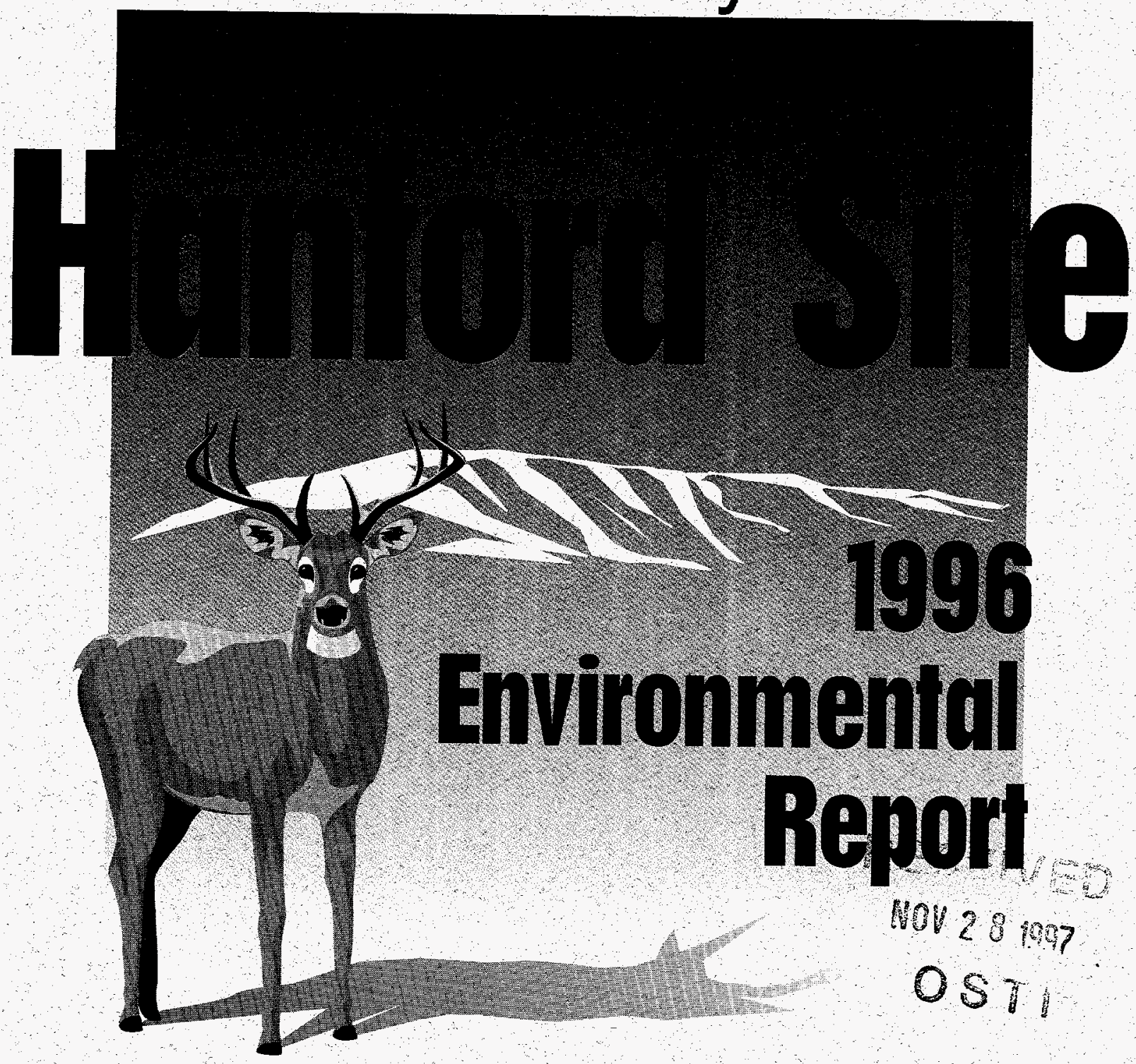

Prepared for the U.S. Depariment of Energy under Contruel DE-ACO6-76RLO 1830

\section{MASTER}

GETRISUMON OF TIS DOCUMENT IS UNLIMITED 


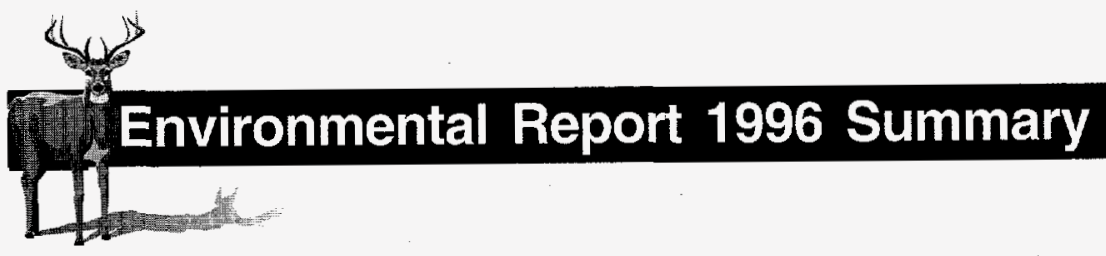

DISCLAIMER

PNNL-11472-SUM

This report was prepared as an account of work sponsored by an agency of the United States Government. Neither the United States Government nor any agency thereof, nor any of their employees, makes any warranty, express or implied, or assumes any legal liability or responsibility for the accuracy, completeness, or usefulness of any information, apparatus, product, or process disclosed, or represents that its use would not infringe privately owned rights. Reference herein to any specific commercial product, process, or service by trade name, trademark, manufacturer, or otherwise does not necessarily constitute or imply its endorsement, recommendation, or favoring by the United States Government or any agency thereof. The views and opinions of authors expressed herein do not necessarily state or reflect those of the United States Government or any agency thereof.

\title{
Summary of the Hanford Site Environmental Report for Calendar Year 1996
}

\author{
Compiled and Edited by \\ R.W. Hanf \\ G. P. O'Connor \\ R.L. Dirkes
}

August 1997

This report was prepared by personnel from Pacific Northwest

National Laboratory, Fluor Daniel Hanford, Inc. and its subcontractors and enterprise companies, Bechtel Hanford, Inc., and MACTEC-ERS for the U.S. Department of Energy. 


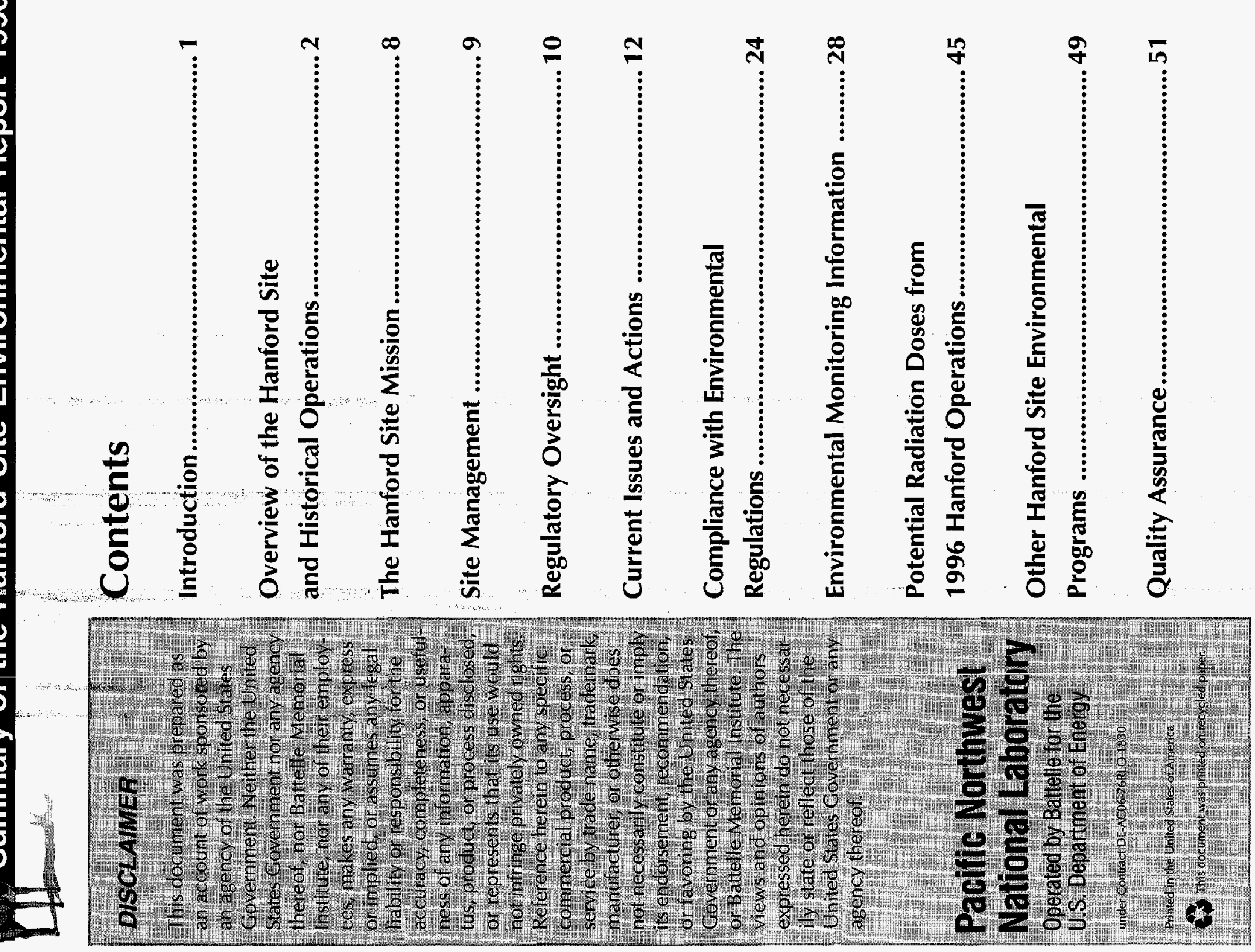




\section{DISCLAMIXR}

Portions of this doemenent may be illegible in electronic image produets. Images are produced frow the best available origion docomenert 


\section{Environmental Report 1996 Summary}

\section{Introduction}

This booklet summarizes the 420-page Hanford Site Environmental Report for Calendar Year 1996. The Hanford Site environmental report is prepared annually to summarize environmental data and information, describe environmental management performance, demonstrate the status of compliance with environmental regulations, and highlight major environmental programs and efforts. The report is written to meet reporting requirements and guidelines of the U.S. Department of Energy (DOE) and to meet the needs of the public.

The summary booklet is designed to briefly

- describe the Hanford Site and its mission

- summarize the status in 1996 of compliance with environmental regulations

- describe environmental programs at the Hanford Site

- discuss estimated radionuclide exposure to the public from 1996 Hanford Site activities

- present information on effluent monitoring and environmental surveillance, including groundwater protection and monitoring

- discuss activities to ensure quality.

This summary booklet has been written with a minimum of technical terminology. Readers interested in more detailed information can consult the 1996 report or the technical documents cited and listed in that report.

Inquiries about this booklet or comments and suggestions about its content, may be directed to the Department of Energy's Richland Operations Office, Environmental Assurance, Permits and Policy Division, P.O. Box 550, Richland, Washington 99352, or to Mr. Roger Dirkes, Pacific Northwest National Laboratory, P.O. Box 999, Richland, Washington 99352. 


\section{Hanford Site}

\section{Overview of the Hanford Site and Historical Operations}

The Hanford Site lies within the semiarid Pasco Basin of the Columbia Plateau in southeastern Washington State (Figure 1). The site occupies an area of approximately 1,450 square kilometers (approximately 560 square miles) located north of the city of Richland and the confluence of the Yakima and Columbia rivers. This large area has restricted public access and provides a buffer for the smaller areas onsite that historically were used for production of nuclear materials, waste storage, and waste disposal. Only approximately $6 \%$ of the land area has been disturbed and is actively used. The Columbia River flows eastward through the northern part of the Hanford Site and then turns south, forming part of the eastern site boundary. The Yakima River flows near a portion of the southern boundary and joins the Columbia River downstream from the city of Richland. The cities of Richland, Kennewick, and Pasco (Tri-Cities) constitute the nearest population center and are located southeast of the site.

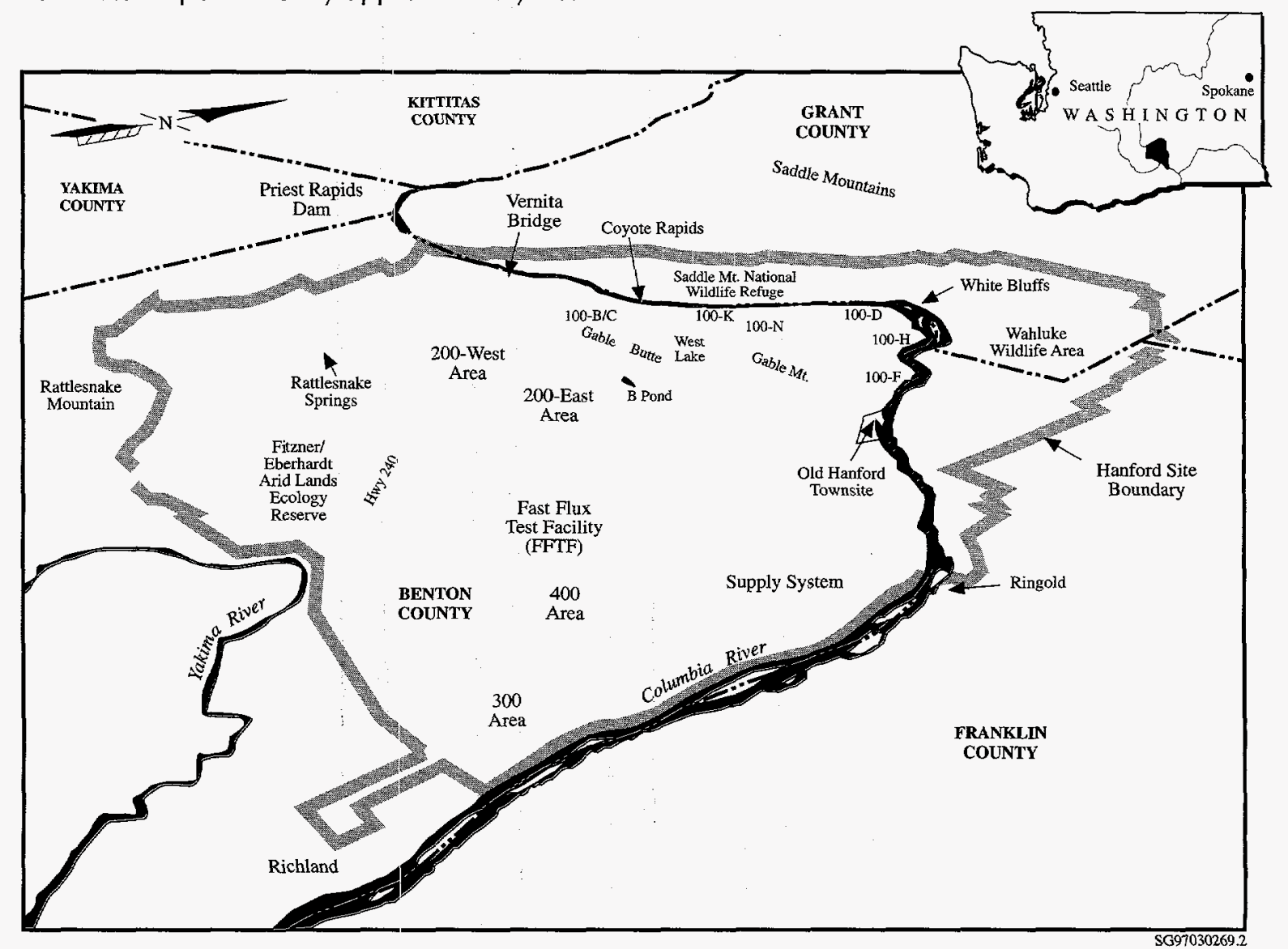

Figure 1. The Hanford Site is located along the Columbia River in southeastern Washington. 


\section{Environmental Report 1996 Summary}

\section{Historical Site Operations}

The Hanford Site was established in 1943 to use technology developed at the University of Chicago and the Clinton Laboratory in Oak Ridge, Tennessee, to produce plutonium for some nuclear weapons tested and used in World War II. Hanford was the first plutonium production facility in the world. The site was selected by the U.S. Army Corps of Engineers because it was remote from major populated areas and had 1) ample electrical power from Grand Coulee Dam, 2) a functional railroad, 3) clean water from the nearby Columbia River, and 4) sand and gravel that could be used for constructing large concrete structures.

Hanford Site operations have resulted in the production of liquid, solid, and gaseous wastes. Most wastes resulting from site operations have had at least the potential to contain radioactive materials. From an operational standpoint, radioactive wastes were originally categorized as "high level," "intermediate level," or "low level," which referred to the level of radioactivity present.

Some high-level solid waste, such as large pieces of machinery and equipment, were placed onto railroad flatcars and stored in underground tunnels. Both intermediate- and low-level solid wastes, consisting of tools, machinery, paper, and wood, were placed into covered trenches at storage and disposal sites known as "burial grounds." Beginning in 1970, solid wastes were segregated according to the makeup of the waste material. Solids containing plutonium and other transuranic materials were packaged in special containers and stored in lined trenches covered with soil for possible later retrieval. High-level liquid wastes were stored in large underground tanks.
Intermediate-level liquid waste streams were usually routed to underground structures of various types called "cribs." Occasionally, trenches were filled with the liquid waste and then covered with soil after the waste had soaked into the ground. Lowlevel liquid waste streams were usually routed to surface impoundments (ditches and ponds). Nonradioactive solid wastes were usually burned in "burning grounds." This practice was discontinued in the late 1960s in response to the Clean Air Act, and the materials were instead buried at sanitary landfill sites. These storage and disposal sites, with the exception of high-level waste tanks, are now designated as "active" or "inactive" waste sites, depending on whether the site currently is receiving wastes.

For security, safety, and functional reasons, the Hanford Site was divided into numbered areas (see Figure 1). The major operational areas include the following:

- The 100 Areas, on the south shore of the Columbia River, are the sites of nine retired plutonium production reactors, including the dual-purpose $\mathrm{N}$ Reactor. The 100 Areas occupy approximately 11 square kilometers (4 square miles).

- The 200-West and 200-East Areas are located on a plateau and are approximately 8 and 11 kilometers (5 and 7 miles), respectively, south of the Columbia River. The 200 Areas cover approximately 16 kilometers (6 miles).

- The 300 Area is located just north of the city of Richland. This area covers 1.5 square kilometers (0.6 mile). 


\section{Hanford Site}

- The 400 Area is approximately 8 kilometers (5 miles) northwest of the 300 Area.

- The 600 Area includes all of the Hanford Site not occupied by the $100,200,300$, and 400 Areas.

Each of these areas and operations conducted within them are described below.

\section{The 300 Area}

From the early 1940 s to the present, most researchand-development activities at the Hanford Site were carried out in the 300 Area (Figure 1). The 300 Area was also the location of nuclear fuel fabrication. Nuclear fuel in the form of pipe-like cylinders (fuel slugs) was fabricated from metallic uranium shipped in from offsite production facilities. Metallic uranium was extruded into the proper shape and encapsulated in aluminum or zirconium cladding. Copper was an important material used in the extrusion process, and substantial amounts of copper, uranium, and other heavy metals ended up in 300 Area liquid waste streams. Initially, these streams were routed to the 300 Area waste ponds, which were located near the Columbia River shoreline. In more recent times, the low-level liquid wastes were sent to process trenches or shipped to a solar evaporation facility in the 100-H Area (183-H Solar Evaporation Basins).

\section{The 100 Areas}

The fabricated fuel slugs were shipped by rail from the 300 Area to the 100 Areas reactors. The main component of the nuclear reactors consisted of a large stack (pile) of graphite blocks that had tubes and pipes running through it. The tubes were receptacles for the fuel slugs while the pipes carried water to cool the graphite pile. Placing large numbers of slightly radioactive uranium fuel slugs into the reactor piles created an intense radiation field and a radioactive chain reaction that resulted in the conversion of some uranium atoms into plutonium atoms. Other uranium atoms were split into radioactive "fission products." The intense radiation field also caused some nonradioactive atoms in the structure to become radioactive "activation products."

The first eight reactors, constructed between 1944 and 1955, used water from the Columbia River for direct cooling. Large quantities of water were pumped through the reactor piles and discharged back into the river. The discharged cooling water contained small amounts of radioactive materials that escaped from the fuel slugs and tube walls, during the irradiation process. The radiation fields in the piles also caused some of the impurities in the river water to become radioactive (neutron activation). The ninth reactor, $\mathrm{N}$ Reactor, was completed in 1963 and was a slightly different design. Purified water was recirculated through the reactor core in a closed-loop cooling system. Beginning in 1966, the heat from the closed-loop system was used to produce steam that was sold to the Washington Public Power Supply System to generate electricity at the adjacent Hanford Generating Plant.

When fresh fuel slugs were pushed into the front face of a reactor's graphite pile, irradiated fuel slugs were forced out the rear into a deep pool of water called a "fuel storage basin." After a brief period of storage in the basin, the irradiated fuel was shipped to the 200 Areas for processing. The fuel was shipped in casks by rail in specially constructed railcars. Most of the irradiated fuel produced by the $N$ Reactor from the early 1970 s to the early 1980 s was the result of electrical production runs. 


\section{Environmental Report 1996 Summary}

This material was not weapons grade, so was never processed for recovery of plutonium.

Beginning in 1975, N Reactor irradiated fuel was shipped to the K East and K West Fuel Storage Basins for temporary storage where it remains today. This fuel accounts for the majority of the total fuel inventory currently stored underwater in the K Basins. From the early 1980 s until its shutdown in 1987, the N Reactor operated to produce weapons-grade material. Electrical production continued during this operating period but was actually a byproduct of the weapons production program. The majority of weapons-grade material produced during these runs was processed in the 200-East Area at the Plutonium-Uranium Extraction Plant prior to its shutdown. The remainder is stored in the K Basins.

\section{The 200 Areas}

The 200-East and 200-West Areas are located on a plateau approximately 11 and 8 kilometers $(7$ and 5 miles), respectively, south of the Columbia River (Figure 1). These areas house facilities that received and dissolved irradiated fuel and then separated out the valuable plutonium. These facilities were called "separations plants." Three types of separations plants were used over the years to process irradiated fuel. Each of the plutonium production processes began with the dissolution of the aluminum or zirconium cladding material in solutions containing ammonium hydroxide/ ammonium nitrate/ammonium fluoride followed by the dissolution of the irradiated fuel slugs in nitric acid. All three separations plants, therefore, produced large quantities of waste nitric acid solutions that contained high levels of radioactive materials. These wastes were neutralized and stored in large underground tanks (Figure 2). Fumes from the dissolution of cladding and fuel, and from other plant processes, were discharged to the atmosphere from tall smokestacks that were filtered after 1950 .

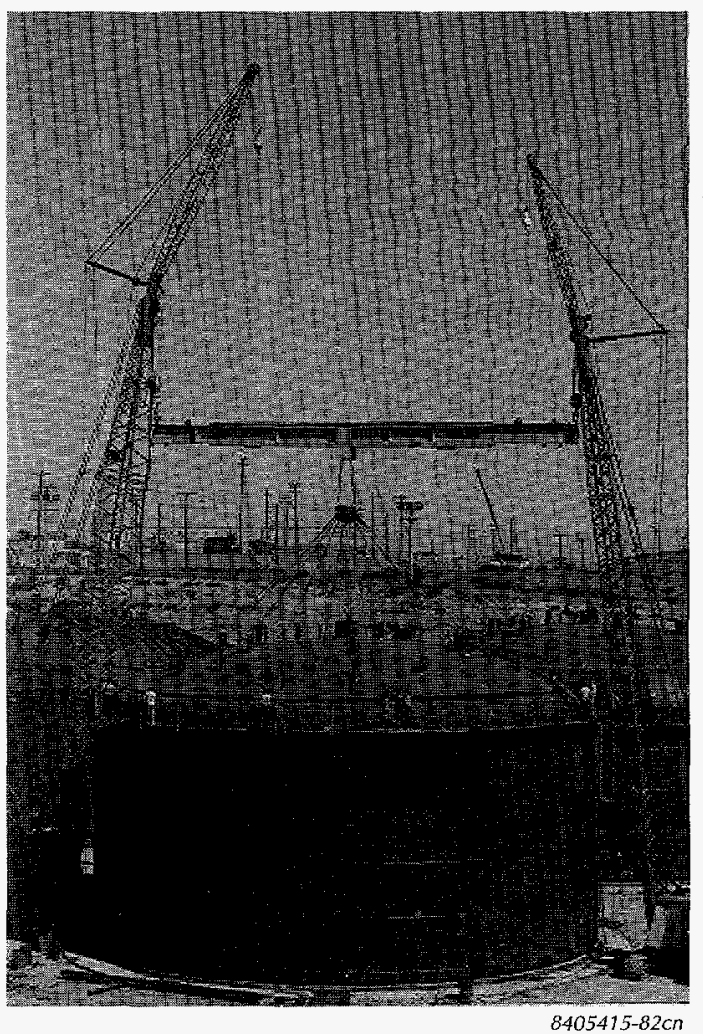

Figure 2. The Hanford Site contains 177 cylindrical underground storage tanks with holding capacities ranging from 55,000 to 1.1 million gallons. These tanks contain 55 million gallons of hazardous and radioactive wastes-enough to fill nearly 2,800 railroad tanker cars.

Both B Plant and T Plant used a "bismuth phosphate" process to precipitate and separate plutonium from acid solutions during the early days of site operations. Leftover uranium and high-level waste products were not separated and were stored together in large underground "single-shell" tanks (i.e., tanks constructed with a single wall of 


\section{Hanford Site}

steel). The leftover uranium was later salvaged, purified into uranium oxide powder at the UraniumTriOxide Plant, and transported to uranium production facilities in other parts of the country for reuse. This salvage process used a solvent extraction technique that resulted in radioactive liquid waste that was discharged to the soil in covered trenches at the BC Cribs area south of the 200-East Area. Cooling water and steam condensates from B Plant went to B Pond, cooling water and steam condensates from T Plant went to T Pond, and cooling water and steam condensates from $U$ Plant and the Uranium-TriOxide Plant were routed to U Pond.

After T Plant stopped functioning as a separations facility, it was converted to a decontamination operation where large pieces of equipment and machinery could be cleaned up for reuse. B Plant was later converted into a facility to separate radioactive strontium and cesium from high-level waste. The strontium and cesium were then concentrated into a solid salt material, melted, and encapsulated at the adjacent encapsulation facility. Canisters of encapsulated strontium and cesium were stored in a water storage basin at the encapsulation facility.

The Reduction-Oxidation Plant and PlutoniumUranium Extraction Plant used solvent extraction techniques to separate plutonium from leftover uranium and radioactive waste products. Most of the irradiated fuel produced at the site was processed at either of these two plants. The solvent extraction method separates chemicals based on their differing solubilities in water and organic solvents (i.e., hexone at the Reduction-Oxidation Plant and tributylphosphate at the PlutoniumUranium Extraction Plant). High-level liquid wastes were neutralized and stored in single-shell tanks (Reduction-Oxidation Plant) or double-shell tanks (Plutonium-Uranium Extraction Plant). Occasionally, organic materials such as solvents and resins ended up in high-level liquid waste streams sent to the tanks. Various chemicals and radioactive materials precipitated and settled to the bottom of the tanks.

This phenomenon was later used to advantage-the liquid waste was heated in special facilities (evaporators) to remove excess water and concentrate the waste into salt cake and sludge, which remained in the tanks. The evaporated and condensed water contained radioactive tritium and was discharged to cribs. Intermediate- and low-level liquid wastes discharged to the soil from the Reduction-Oxidation and Plutonium-Uranium Extraction Plants typically contained tritium and other radioactive fission products as well as nonradioactive nitrate. Intermediatelevel liquid wastes discharged to cribs from the Reduction-Oxidation Plant sometimes contained hexone used in the reduction oxidation process. Cooling water from the Reduction-Oxidation Plant was discharged to the $S$ Ponds. Cooling water from the Plutonium-Uranium Extraction Plant was discharged to Gable Mountain Pond and B Pond.

The Reduction-Oxidation and Plutonium-Uranium Extraction Plants produced uranium nitrate for recycle and plutonium nitrate for weapons component production. Uranium nitrate was shipped by tank truck to the Uranium-TriOxide Plant for processing. The Uranium-TriOxide Plant used specially designed machinery to heat the uranium nitrate solution and boil off the nitric acid, which was recovered and recycled to the separations plants. The product, uranium oxide, was packaged and shipped to other facilities in the United States for recycle. Plutonium nitrate, in small quantities for safety reasons, was placed into special shipping containers ( $P-R$ cans) and hauled by truck to Z Plant (later called the Plutonium Finishing Plant) for further processing. 


\section{Environmental Report 1996 Summary}

The purpose of Plutonium Finishing Plant operations was to convert the plutonium nitrate into plutonium metal blanks (buttons) that were manufactured offsite into nuclear weapons components. The conversion processes used nitric acid, hydrofluoric acid, carbon tetrachloride, and various oils and degreasers. Varying amounts of all these materials ended up in the intermediate-level liquid wastes that were discharged to cribs. Cooling water from the Plutonium Finishing Plant was discharged via open ditch to $U$ Pond. High-level solid wastes containing plutonium were segregated and packaged for storage in special earth-covered trenches.

\section{The 400 Area}

In addition to research-and-development activities in the 300 Area, the Hanford Site has supported several test facilities. The largest is the Fast Flux Test Facility located approximately 8 kilometers (5 miles) northwest of the 300 Area. This special nuclear reactor was designed to test various types of nuclear fuel. The facility operated for approximately 13 years and was shut down in 1993. The reactor was a unique design that used liquid metal sodium as the primary coolant. The heated liquid sodium was cooled with atmospheric air in heat exchangers. Spent fuel from the facility resides in the 400 Area, while other wastes were transported to the 200 Areas. With the exception of the spent fuel, no major amounts of radioactive wastes were stored or disposed of at the Fast Flux Test Facility site. The facility is presently under consideration for a short-term mission in the production of tritium. Tritium, a necessary ingredient in some nuclear weapons, decays relatively quickly so must be replenished. The production of medical isotopes is also under consideration as a long-term mission.
Medical isotopes are radioactive elements that are useful for the treatment of medical conditions such as cancer.

\section{Richland Areas}

Support areas near the site in north Richland include the 1100 and Richland North Areas. The 1100 Area includes site support services such as general stores and transportation maintenance. The Richland North Area includes the U.S. Department of Energy (DOE) and DOE contractor facilities, mostly office buildings, located between the 300 Area and the city of Richland that are not in the 1100 Area. During 1996, the 3000 Area was cleaned up and vacated by DOE and its contractors. All land and facilities within the area were turned over to the Port of Benton, and the 3000 Area designation was retired.

\section{Other Areas}

Several areas of the site, totaling 665 square kilometers (257 square miles), have special designations. These include the Fitzner/Eberhardt Arid Lands Ecology Reserve, the U.S. Fish and Wildlife Service Saddle Mountain National Wildlife Refuge, and the Washington State Department of Game Reserve Area (Wahluke Slope Wildlife Recreation Area). The Fitzner/Eberhardt Arid Lands Ecology Reserve was established in 1967 by the U.S. Atomic Energy Commission, a precursor to DOE. In 1971, the reserve was classified a Research Natural Area as a result of a federal interagency cooperative agreement. Planning is currently under way to transfer management of the Fitzner/Eberhardt Arid Lands Ecology Reserve from the DOE to the U.S. Fish and Wildlife Service. That plan calls for the eventual designation of the reserve as part of the National Wildlife Refuge system. 


\section{Hanford Site}

\section{The Hanford Site Mission}

For more than 40 years, Hanford Site facilities were dedicated primarily to producing plutonium for national defense and managing the resulting wastes. In recent years, efforts at the site have focused on developing new waste treatment and disposal technologies and cleaning up contamination left over from historical operations.

The current site mission includes the following:

- management of wastes and the handling, storage, and disposal of radioactive, hazardous, mixed, or sanitary wastes from current operations

- stabilizing facilities by transferring them from an operating mode to a surveillance and maintenance mode

- maintenance and cleanup of several hundred inactive radioactive, hazardous, and mixed waste disposal sites (there are over 2,200 waste sites of all kinds at Hanford); remediation of contaminated groundwater; and surveillance, maintenance, and decommissioning of inactive facilities

- research and development in energy, health, safety, environmental sciences, molecular sciences, environmental restoration, waste management, and national security

- development of new technologies for environmental restoration and waste management, including site characterization and assessment methods; waste minimization, treatment, and remediation technology.
DOE has set a goal of cleaning up Hanford's waste sites and bringing its facilities into compliance with local, state, and federal environmental laws. In addition to supporting the environmental management mission, DOE also is supporting other special initiatives in accomplishing its national objective.

Current waste management activities at the Hanford Site include, primarily, managing wastes with high and low levels of radioactivity (from the nuclear materials production activities) in the 200-East and 200-West Areas. Key waste management facilities include the underground waste storage tanks, Environmental Restoration Disposal Facility, Plutonium Finishing Plant, Central Waste Complex, Low-Level Burial Grounds, B PlantWaste Encapsulation Facility, Effluent Treatment Facility, Waste Receiving and Processing Facility, Transuranic Storage and Assay Facility, and 242-A Evaporator. In addition, irradiated nuclear fuel is stored in the 100-K Area in fuel storage basins.

Environmental restoration includes activities to decontaminate and decommission facilities and to clean up or restore inactive waste sites. The Hanford surplus facilities program conducts surveillance and maintenance of such facilities; the cleanup and disposal of more than 100 facilities have begun.

Research and technology-development activities are intended to improve the techniques and reduce the costs of waste management, environmental protection, and site restoration. 


\section{Environmental Report 1996 Summary}

\section{Site Management}

Hanford Site operations and activities are managed by the DOE Richland Operations Office through prime contractors and numerous subcontractors. Each contractor is responsible for safe, environmentally sound maintenance and management of its activities or facilities and operations; for waste management; and for monitoring operations and effluents to ensure environmental compliance.

\begin{abstract}
Principal contractors and their respective responsibilities are Fluor Daniel Hanford, Inc. (management and integration), Battelle Memorial Institute (research and development), Bechtel Hanford, Inc. (environmental restoration), and Hanford Environmental Health Foundation (occupational and environmental health services).
\end{abstract}

\section{Hanford at a Glance}

Location: The U.S. Department of Energy's Hanford Site is located in southeastern

Washington near the city of Richland.

Dominant Feature:
Rattesnake Mountain on the Iitzner/Eberhardt Arid Lands Ecology Reserve
rises 1,074 meters $(3,525$ feet) above the Columbia River Plain.

Size: $\quad$ The site covers approximately 1,450 kilometers ( 560 square miles).

\begin{tabular}{|ll}
\hline Employees: & DOE and its contractors employ 11,400 workers. \\
\hline Mission: & $\begin{array}{l}\text { Hanford's missions are to safely clean up and manage the site's legacy wastes } \\
\text { and to develop and deploy science and technology. }\end{array}$
\end{tabular}

Budget: The budget for Fiscal Year 1997 (October 1996 -September 1997 ) is 1) approximately $\$ 2$ billion.

History: $\quad$ Hanford was established in secrecy during World War II to produce plutonium for America's nuclear weapons. Peak production years were reached in the 1960 s when nine production reactors were in operation at the site. All weapons material production was halted in the late 1980s, and the site is now engaged in the world's largest environmental cleanup project.

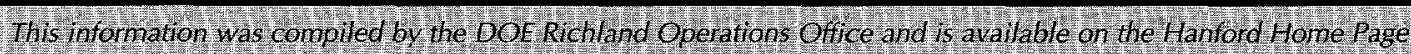
(htp:wwwharfordgovit 


\section{Hanford Site}

\section{Regulatory Oversight}

Several local, state, and federal government agencies are responsible for monitoring and enforcing compliance with applicable environmental regulations at the Hanford Site. The major agencies include the U.S. Environmental Protection Agency (EPA), Washington State Department of Ecology, Washington State Department of Health, and Benton County Clean Air Authority. These agencies issue permits, review compliance reports, participate in joint monitoring programs, inspect facilities and operations, and oversee compliance with applicable regulations. DOE, through compliance audits and its directives to field offices, initiates and assesses actions for compliance with environmental requirements. The primary requirements address environmental air quality, water quality, land use, cultural resources, and waste management.

EPA is the principal federal environmental regulator. EPA develops, promulgates, and enforces environmental protection regulations and technologybased standards as directed by statutes passed by Congress. In some instances, EPA has delegated environmental regulatory authority to the state or authorized the state program to operate in lieu of the federal program when the state's program meets or exceeds EPA's requirements. For instance, EPA has delegated or authorized certain enforcement authorities to the Washington State Department of Ecology for air pollution control and many areas of hazardous waste management. In other activities, the state program is assigned direct oversight over federal operating agencies as provided by federal law. For example, the Washington State Department of Health has direct authority under the Clean Air Act to enforce the federal program for regulating radionuclide air emissions at the Hanford Site. Where federal regulatory authority is not delegated or authorized to the state, EPA Region 10 is responsible for reviewing and enforcing compliance with EPA regulations as they pertain to the Hanford Site.

Although the state of Oregon does not have direct regulatory authority at Hanford, DOE recognizes its interest in site cleanup because of Oregon's location downstream along the Columbia River. There is also the potential for shipping radioactive wastes from Hanford through Oregon by rail, truck, or barge. Oregon participates in the State and Tribal Government Working Group for the Hanford Site, which reviews the site's cleanup plans.

\section{The Role of Indian Tribes}

The Hanford Site is located on land ceded by treaties with the Yakama Indian Nation and the Confederated Tribes of the Umatilla Indian Reservation in 1855. The Nez Perce Tribe has treaty fishing rights on the Columbia River. The tribes reserved the right to fish "at all usual and accustomed places" and the privilege to hunt, gather roots and berries, and pasture horses and cattle on "open unclaimed" land. The Wanapum people are not a federally recognized tribe, and are therefore ineligible for federal programs. However, they have historical ties to the Hanford Site and are routinely consulted regarding cultural and religious freedom issues.

In addition to the American Indian Policy, laws such as the American Indian Religious Freedom 


\section{Environmental Report 1996 Summary}

Act, the Archaeological Resources Protection Act, the National Historic Preservation Act, and the Native American Graves Protection and Repatriation Act require consultation with tribal governments. The combination of the Treaties of 1855, federal policy, and laws and regulations provide the basis for tribal participation in Hanford plans and activities.

\section{Public Participation}

Individual citizens of the state of Washington and neighboring states may influence Hanford Site cleanup decisions through public participation activities (Figure 3). The public has opportunities to provide their input and influence decisions through many forums, including Hanford Advisory Board meetings, activities related to the Hanford Federal Facility Agreement and Consent Order (Tri-Party Agreement), National Environmental Policy Act public meetings covering various environmental impact statements and environmental assessments, and many other outreach programs.

To apprise the public of upcoming opportunities for public participation, the Hanford Update, a synopsis of all ongoing and upcoming Tri-Party Agreement public involvement activities, is published bimonthly. In addition, the Hanford Happenings calendar, which highlights Tri-Party Agreement scheduled meetings and comment periods, is distributed each month.
Most of Hanford's public resides in Washington, Oregon, and Idaho. To allow them better access to up-to-date Hanford information, four information repositories have been established. They are located in Richland, Seattle, and Spokane, Washington, and Portland, Oregon.

The three parties respond to questions that are received via a toll-free telephone line (1-800-321-2008). Members of the public can request information about any public participation activity and receive a response by contacting DOE's Richland Operations Office of External Affairs at (509) 376-7501.

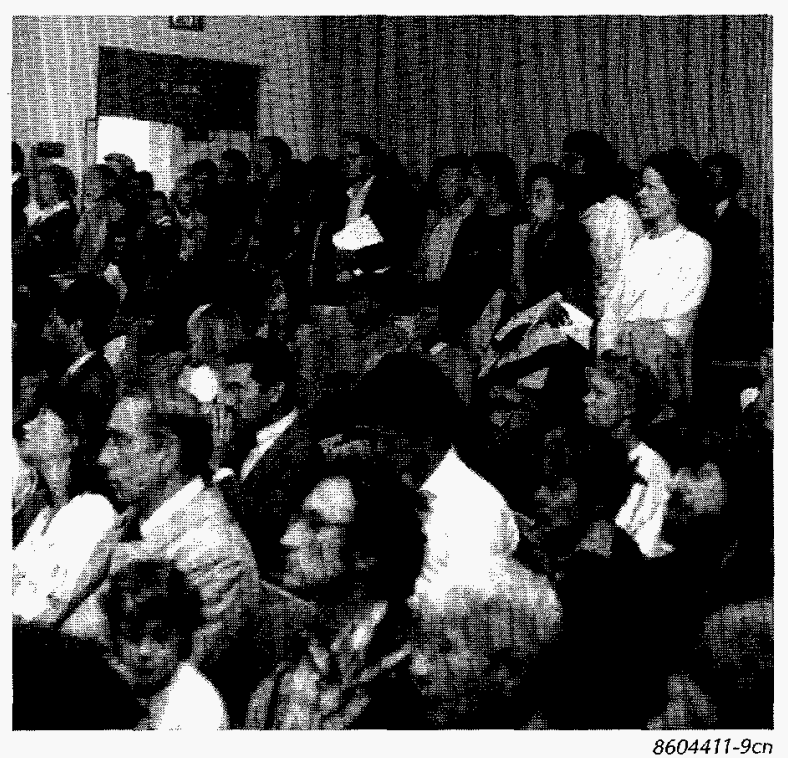

Figure 3. Pacific Northwest citizens provide input at public meetings on site cleanup. 


\section{Current Issues and Actions}

\section{Hanford Federal Facility Agreement and Consent Order (Tri-Party Agreement)}

The Tri-Party Agreement is an agreement among the EPA, Washington State Department of Ecology, and DOE for achieving compliance with the remedial action provisions of the Comprehensive Environmental Response, Compensation, and Liability Act and with treatment, storage, and disposal unit regulation and corrective action provisions of the Resource Conservation and Recovery Act.

From 1989 through 1996, a total of 512 enforceable Tri-Party Agreement milestones and 223 unenforceable target dates were completed on or ahead of schedule. Sixty-four milestones scheduled for 1996 were completed. Sixty-four Tri-Party Agreement milestones scheduled for 1996 were completed.

Since the last issue of this report, new negotiated changes to the Tri-Party Agreement established 99 new enforceable milestones and 25 new unenforceable target dates.

\section{Tank Waste Remediation System Approved Changes}

The DOE completed an analysis of privatization of low-activity waste pretreatment and immobilization options for cleanup of the radioactive and hazardous tank wastes in the sing $\mid \mathrm{e}$ - and doubleshell underground storage tanks at Hanford. The Tank Waste Remediation System mission is to conceptualize, develop, design, construct, and operate the physical systems and technologies necessary to retrieve waste from these 177 tanks located in the 200-East and 200-West Areas and convert the waste into a solid suitable for ultimate disposal. Under the privatization approach, private companies under contract with DOE will treat Hanford's tank wastes and return a treated product to DOE.

\section{Pollution Prevention Program}

The Hanford Site Pollution Prevention Program is an organized, comprehensive, and continual effort to systematically reduce the quantity and toxicity of hazardous, radioactive, mixed, and sanitary wastes. Also, the program fosters the conservation of resources and energy, the reduction of hazardous substance use, and the prevention or minimization of pollutant releases to all environmental media from all operations and site cleanup activities.

The program is designed to satisfy DOE requirements, executive orders, and state and federal regulations and requirements. In accordance with sound environmental management, preventing pollution through source reduction is the first priority in this pollution prevention program, and the second priority is environmentally safe recycling. Waste treatment to reduce quantity, toxicity, or mobility (or a combination of these) will be considered only when prevention and recycling are not possible or practical. Environmentally safe disposal is the last option.

Hanford Site pollution prevention efforts in 1996 helped to prevent the generation of 2,900 cubic meters $(3,800$ cubic yards) of radioactive mixed waste, 174 metric tons (191 tons) of Resource Conservation and Recovery Act hazardous/dangerous 


\section{Environmental Report 1996 Summary}

waste, 342 million liters (90 million gallons) of process waste water, and 12,600 metric tons $(13,800$ tons) of sanitary waste. Total savings in 1996 exceeded $\$ 15,600,000$ for these activities.

During 1996, the Hanford Site recycled 595 metric tons (655 tons) of office paper, 57 metric tons (62 tons) of cardboard, 2,000 metric tons $(2,200$ tons) of ferrous metal, 175 metric tons (190 tons) of nonferrous metal, 21 metric tons (23 tons) of lead, 22 metric tons ( 24 tons) of solid chemicals, 86,000 liters (23,000 gallons) of liquid chemicals, 200 kilograms (440 pounds) of aerosol cans, 8,400 kilograms ( 18,500 pounds) of fluorescent light tubes, and 48,000 kilograms $(105,000$ pounds) of lead acid/gel cell batteries. Savings in 1996 exceeded $\$ 1,750,000$ based on disposal costs.

Numerous generator-specific initiatives were put into place that enabled these waste reductions and cost savings. To celebrate these pollution prevention activities, the "Hanford Pollution Prevention Accomplishments Book" was published in September 1996. The book outlines 45 initiatives that were implemented and are now in use at locations throughout the Hanford Site.

\section{Environmental and Molecular Science Laboratory}

In October 1996, the Environmental and Molecular Science Laboratory was officially dedicated by Secretary of Energy Hazel $O^{\prime}$ Leary as the William R. Wiley Environmental and Molecular Science Laboratory. This dedication highlighted a year where construction neared completion. Major pieces of research equipment were received and installed in the facility, including a new state-ofthe-art computing system and an ion accelerator.
When finished, the 18,600-square meter (200,200-square feet) facility will accommodate up to 270 permanent staff, visiting scientists, postdoctoral researchers, and students who will work to develop the science and technology needed to clean up environmental contaminants at government and industrial sites across the country.

\section{Waste Tank Safety Issues}

The Waste Tank Safety Program, now called Safety Issue Resolution Projects, was established in 1990 to address the hazards associated with storage of radioactive mixed waste in the 177 large underground storage tanks at the Hanford Site. The projects serve as the focal point for identifying and resolving selected high-priority waste tank safety issues. Tanks with the highest risk are being evaluated and mitigated first. Table 1 shows the status of the 177 waste tanks as of December 1996. So far, 115 single-shell tanks have been stabilized, with the tank stabilization program to be completed in 2000 . At the end of 1996, 108 single-shell tanks

Table 1. Status of Hanford Site Waste Tanks as of December 1996

\begin{tabular}{lcc} 
& $\begin{array}{c}\text { Single-Shell } \\
\text { Tanks }\end{array}$ & $\begin{array}{c}\text { Double-Shell } \\
\text { Tanks }\end{array}$ \\
$\begin{array}{l}\text { Number of Waste } \\
\text { Tanks (177 total) }\end{array}$ & 149 & 28 \\
\hline $\begin{array}{l}\text { Tanks listed as } \\
\text { "Assumed Leaker" }\end{array}$ & 0 \\
\hline $\begin{array}{l}\text { Ferrocyanide Tanks } \\
\text { on Watch List }{ }^{\text {ta) }}\end{array}$ & 0 \\
\hline $\begin{array}{l}\text { Flammable Gas Tanks } \\
\text { on Watch List }\end{array}$ & 19 \\
\hline $\begin{array}{l}\text { Organic Tanks on } \\
\text { Watch List } \\
\text { (a) All 18 single-shell tanks were removed from the Watch List } \\
\text { in } 1996 .\end{array}$
\end{tabular}




\section{Hanford Site}

had intrusion prevention devices completed, and 51 single-shell tanks were disconnected and capped to avoid inadvertent liquid additions to the tanks. Figures 4 and 5 show cross sections of single- and double-shell tanks.

The total estimated volume to date of radioactive waste leakage from single-shell tanks is 2.3 million to 3.4 million liters $(600,000$ to 900,000 gallons $)$.

\section{Watch List Tanks}

In early 1991, all Hanford Site high-level waste tanks were evaluated and organized into categories to ensure increased attention and monitoring (Figure 6). Other safety concerns, including the possibility of nuclear criticality in a waste tank, also have been addressed.

Ferrocyanide. The ferrocyanide safety issue, which was an earlier concern, involved the potential for

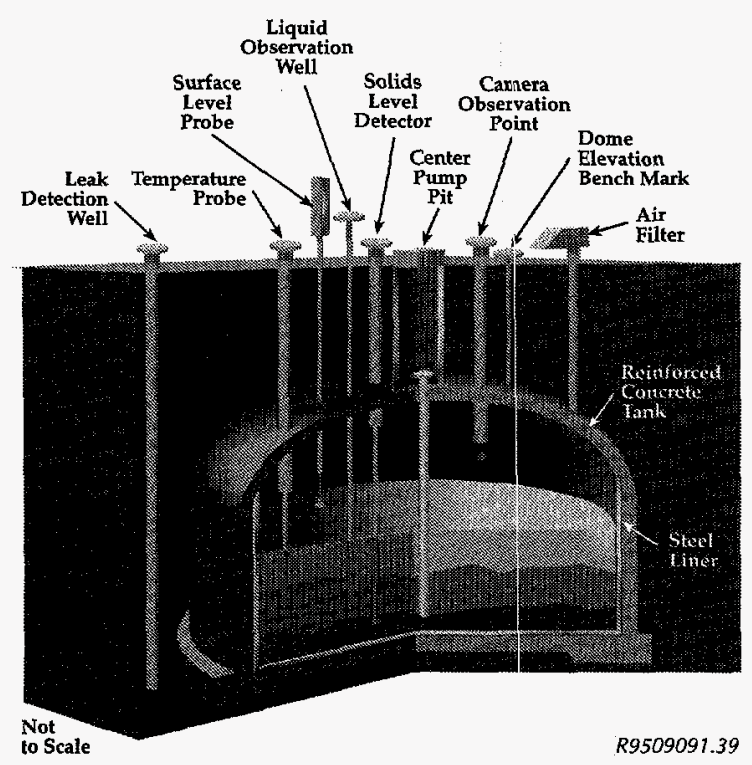

Figure 4. A typical single-shell tank has access ports and risers available for monitoring or other entry needs such as waste sampling.

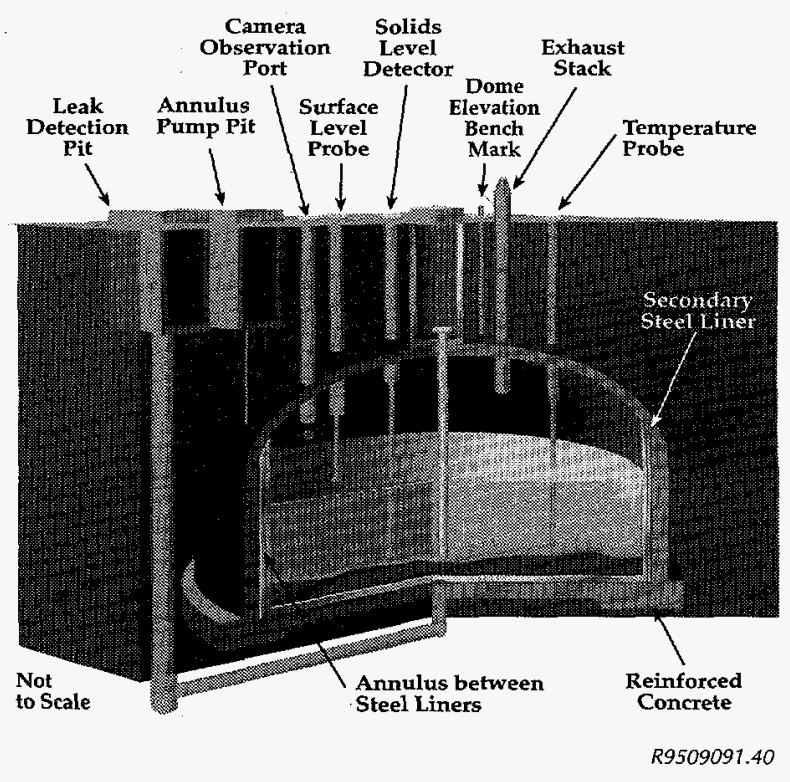

Figure 5. A typical double-shell tank has many ports and risers used for monitoring the tank and surrounding environment.

uncontrolled exothermic reactions of ferrocyanide and nitrate/nitrite mixtures. If ferrocyanide is present, laboratory studies have shown that temperatures must exceed $250^{\circ} \mathrm{C}\left(482^{\circ} \mathrm{F}\right)$ for a reaction to propagate. The hottest temperature in ferrocyanide tanks formerly on the Watch List is $53^{\circ} \mathrm{C}$ $\left(127^{\circ} \mathrm{F}\right)$ and decreasing.

In October 1990, an unreviewed safety question was declared for the former ferrocyanide tanks because safety was not adequately defined by existing analyses. However, the unreviewed safety question was closed by DOE in March 1994 as a result of significant knowledge gained from simulant studies, conservative theoretical analyses, and analyses of actual waste samples that allowed bounding safety criteria to be defined and applied to each tank. 


\section{Environmental Report 1996 Summary}

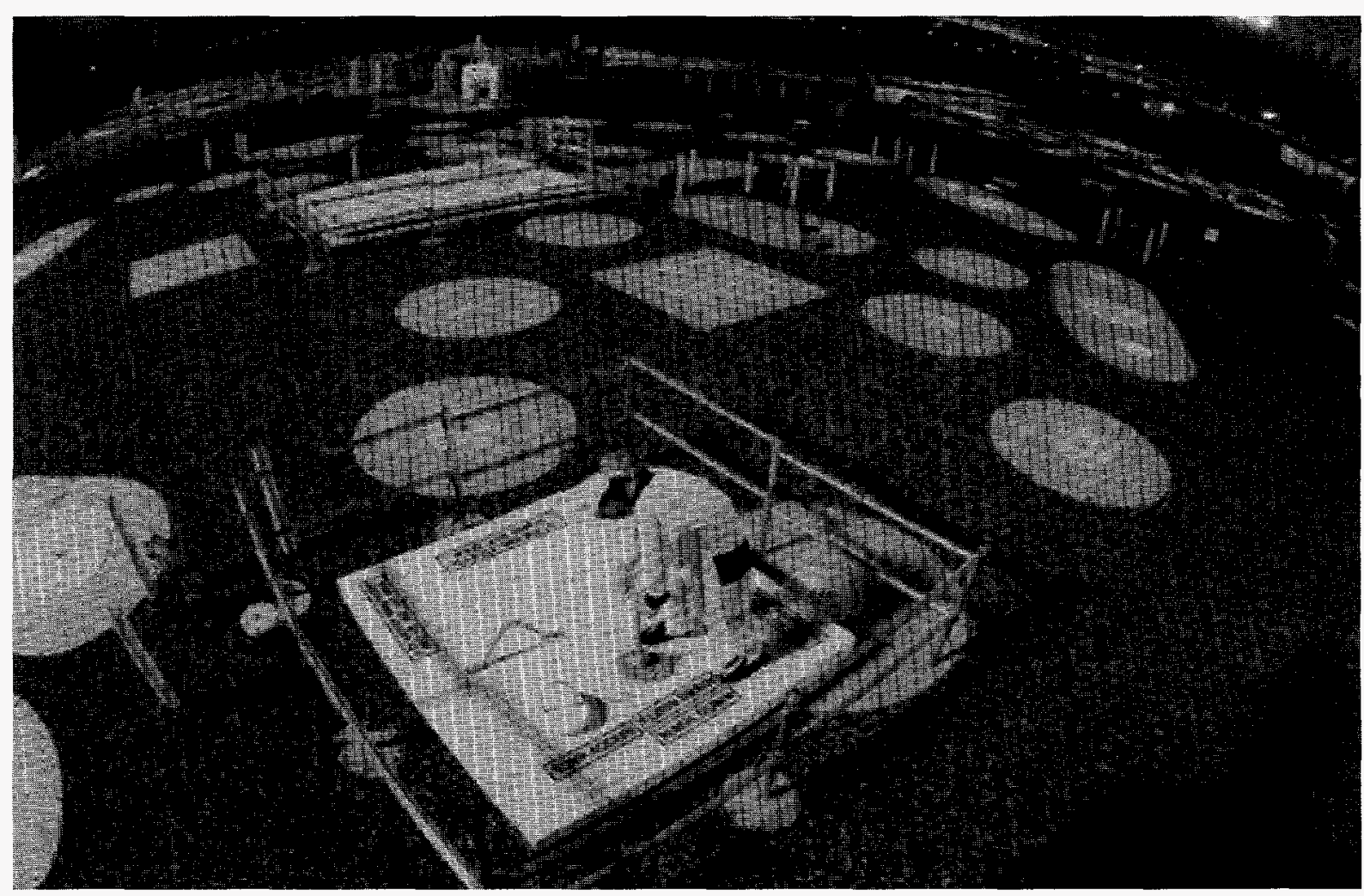

Figure 6. Workers monitor the status of Hanford waste tanks every day.

$88101363-44 \mathrm{cn}$

There were originally 24 ferrocyanide tanks on the Watch List: 4 were removed in 1993, 2 in 1994, 4 in June 1996, and 14 in September 1996. The ferrocyanide levels have decreased by at least $90 \%$, and in some cases by $99 \%$, over those originally added to the tanks. Experimental studies and core samples from 10 of the ferrocyanide tanks show that hydrolysis and radiolysis of the ferrocyanide occurred, and sufficient fuel to be of concern is no longer present. DOE approved resolution of the ferrocyanide safety issue in December 1996.

Flammable Gas. The flammable gas safety issue involves the generation, retention, and potential release of flammable gases by the waste. Previously, 25 tanks were identified and placed on the Watch List. In prior years, work controls were instituted to prevent introduction of spark sources into these tanks, and evaluations were completed to ensure that installed equipment was intrinsically safe.

The worst-case tank (241-SY-101) was successfully mitigated in 1994 with the installation of a mixing pump. The pump is operated up to three times a week to mix the waste and release gases that are generated and retained in the waste. This mitigation technique has been completely successful, and no episodic releases of gas have occurred since the pump was installed. Two spare mixer pumps are available in the event the original pump should fail.

Hydrogen monitors have been installed on all 25 flammable gas tanks. These monitors, called 


\section{Hanford Site}

standard hydrogen monitoring systems, consist of a cabinet equipped with piping and instrumentation that support an on-line hydrogen detector and a "grab" sampler. Documentation to close the unreviewed safety question for the SY Tank Farm was submitted to DOE in 1995 for closure action. Approval for tank 241-SY-101 to be removed from the unreviewed safety question list was received in June 1996. In November 1996, the unreviewed safety question for the other tanks was expanded to cover 176 underground waste tanks (241-SY-101 is not included) and all auxiliary tank farm tanks. Standard hydrogen monitoring systems are being added to a number of these waste tanks.

Additional instrumentation for determining waste properties and tank behavior has been developed for use in the flammable gas tanks. These instruments include viscometers for measuring the viscosity of the waste in the tanks, in-tank void fraction meters that determine the amount of gas in a given volume of waste, retained gas samplers that capture a waste sample in a gas-tight chamber and allow the gas composition and volume to be measured after the apparatus is brought into a hot cell, and gas characterization systems that allow a broad spectrum of dome-space gases (including hydrogen, ammonia, and nitrous oxide) to be continuously monitored in selected tanks. All of these devices became operational in 1996.

In November 1996, more stringent flammable gas controls were placed on all 177 high-level waste storage tanks after several events occurred where hydrogen gas was found at significant levels in a waste tank undergoing interim stabilization and in another tank being core sampled. All rotary-mode sampling using the sampling trucks was suspended until a safety assessment covering this method is approved for tanks because they might be retaining pockets of gas within the waste matrix.
The Tri-Party Agreement milestone for resolution of the flammable gas safety issue is scheduled for September 2001.

High-Heat Tank. This safety issue concerns tank 241-C-106, a single-shell tank that requires water additions and forced ventilation for evaporative cooling. Without the water additions, which would have to be severely restricted in the event of a tank leak, the tank could exceed structural temperature limits, resulting in potential concrete degradation and possible tank collapse. This tank is scheduled for retrieval, starting in 1998, and transfer of the waste to a double-shell tank. Doubleshell tanks are designed to better handle heatbearing materials than single-shell tanks. As part of the retrieval program, a refrigerated chiller system has been installed to remove radioactive decay heat and the heat generated by the waste transfer pumps. The chiller is scheduled to come on-line in 1997.

The Tri-Party Agreement milestone for resolution of the high-heat safety issue is scheduled for September 2001, with an interim milestone to start retrieval of the waste in tank $241-\mathrm{C}-106$ by October 1997 . This interim milestone is being renegotiated to start sluicing in September 1998.

Organic Tanks. The organic tanks safety issue involves the potential for uncontrolled exothermic reactions of organic chemicals and nitrates/nitrites or organic solvents also present in some of the tanks. During 1995, as part of the vapor sampling program, it was shown that organic vapors in the organic tanks are too low in concentration to exceed even $25 \%$ of their lower flammability limits. 


\section{Environmental Report 1996 Summary}

Criteria to screen tanks for possible organic compounds also were established based on analyses and simulant testing. Tank waste was screened against these criteria, using historic and recent sampling data. Concentrations and temperatures required to support propagating exothermic reactions are comparable to those for ferrocyanide. In addition, moisture levels of 20 weight percent, and less in some cases, will prevent reactions from propagating regardless of the fuel concentration. To determine if adequate moisture is present in the waste, special surface monitoring instrumentation is being developed, and full-depth core sampling of waste in organic tanks is continuing.

Work controls were implemented in 1990 to prevent the introduction of ignition sources into these tanks. In May 1994, vapor sampling and safety analyses were completed that provided the technical basis for closing the unreviewed safety question on the flammability of the floating organic layer in tank 241-C-103. Ten tanks that contained organic complexants were added to the Watch List following a review of sampling data and waste transfer records.

Other work indicates that aging processes have destroyed or significantly lowered the energy content of the organic tanks, making them less hazardous. Additional work shows that most organic complexants used during nuclear fuel reprocessing at the Hanford Site and the primary degradation products of tributyl phosphate are water soluble in nitrate/nitrite salt solutions. Thus, a high percentage of reactive organic chemicals are removed from the single-shell tanks when their pumpable liquid supernatant is pumped out as part of the interim stabilization process for the single-shell tanks.
During 1995 and 1996, waste samples from the organic tanks were taken to determine the quantities of organic constituents present in each tank. Most of the organics found have been of low energy. None of the samples show any tendency to propagate when tested in a special tube propagation calorimeter. Tank characterization reports have been or are being prepared for each of the sampling events. The Tri-Party Agreement milestone for resolution of the organic tanks safety issue is scheduled for September 2001.

Criticality. The unreviewed safety question on the potential for criticality in the high-level waste tanks was closed in 1994 by completing additional analyses, strengthening tank criticality prevention controls, and improving administrative procedures and training. In 1996, an extensive effort was put forth to provide the technical basis for resolving the criticality safety issue. Technical studies were completed that showed a criticality event within a high-level waste tank is not likely during storage. All the single- and double-shell tanks at the Hanford Site contain sufficient neutron absorbers to ensure safe storage; however, additional sampling and controls will be required for retrievaland pretreatment-related activities. A potential criticality safety issue still remains for waste transfers required as part of the retrieval and pretreatment processes. A request to close the criticality safety issue was forwarded to DOE for approval in September 1996. It is expected to be approved during 1997. The Tri-Party Agreement milestone for resolution of the criticality safety issue is scheduled for September 1999. 


\section{Hanford Site}

\section{Waste Immobilization}

Approximately 215 million liters ( 55 million gallons) of radioactive and hazardous wastes accumulated from over 40 years of plutonium production operations are stored in 149 underground single-shell tanks and 28 underground double-shell tanks. Current plans are to pretreat the waste and then solidify it into a glass matrix (vitrification). Pretreatment will separate the waste into a low-radioactivity fraction and a high-radioactivity, including transuranic, fraction. The bulk of the radionuclides will then be in the high-radioactivity and transuranic fraction.

In separate facilities, both fractions will be vitrified, a process that will destroy or extract organic constituents, neutralize or deactivate dangerous waste characteristics, and immobilize toxic metals. The immobilized low-radioactivity fraction will be disposed of in a near-surface facility on the Hanford Site in a retrievable form. The immobilized highradioactivity fraction will be stored onsite until a geologic repository is available offsite for permanent disposal. Tri-Party Agreement milestones specify December 2028 for completion of pretreatment and immobilization of the tank wastes.

\section{Solid Waste Management Activities}

\section{Waste Receiving and Processing Facility}

In March 1997, the first major solid waste processing facility associated with cleanup of the Hanford Site began operations. The Waste Receiving and Processing Facility Module 1 is staffed to analyze, characterize, and prepare drums and boxes for disposal of waste resulting from plutonium operations at Hanford. The Tri-Party Agreement mandates construction and operation of this module. Wastes destined for the Waste Receiving and Processing Facility include Hanford's current inventory of more than 37,000 drums of stored waste as well as materials generated by future site cleanup activities across the DOE complex. Consisting primarily of clothing, gloves, face masks, small tools, and particulates suspected of being contaminated with plutonium, waste containers may also contain other radioactive materials and hazardous components. Processed waste that qualifies as low-level waste and meets disposal requirements will be buried directly at the Hanford Site.

\section{Navy Reactor Compartments}

Seven defueled United States Navy reactor compartment disposal packages were received and placed in Trench 94 in the 200-East Area during 1996. This brings the total number received to 61 . The compartments originate from decommissioned nuclear-powered submarines.

The reactor compartment disposal packages are being regulated by Washington State as dangerous waste because of the presence of lead used as shielding and by EPA because of the presence of small amounts of polychlorinated biphenyls tightly bound within the composition of solid materials such as thermal insulation, cable coverings, and rubber. Also, the compartments are regulated as mixed waste because of radioactivity in addition to dangerous waste.

\section{Liquid Effluent Activities}

\section{2-A Evaporator}

Available storage space to support remediation of the tank waste and cleanup of the Hanford Site is limited in the double-shell tanks. The 242-A Evaporator in the 200-East Area processes double-shell 


\section{Environmental Report 1996 Summary}

tank waste into a concentrate (that is returned to the tanks) and a process condensate stream. The evaporator had one processing campaign in 1996. Dilute waste from the double-shell tanks was processed, resulting in an average waste volume reduction of $88.5 \%$ while producing 4.8 million liters (1.3 million gallons) of process condensate. Two campaigns are scheduled for 1997.

Effluent treatment and disposal capabilities are available to support the continued operation of the evaporator. The 200 Areas Effluent Treatment Facility near the 200-East Area was constructed to treat the process condensate. The process condensate is temporarily stored in the Liquid Effluent Retention Facility while awaiting treatment in the 200 Areas Effluent Treatment Facility. Cooling water and nonradioactive steam condensate from the evaporator will be discharged to the 200 Areas Treated Effluent Disposal Facility starting in 1997.

\section{Liquid Effluent Retention Facility}

The Liquid Effluent Retention Facility consists of three Resource Conservation and Recovery Actcompliant surface impoundments for storing process condensate from the 242-A Evaporator. The facility provides equalization of the flow and $\mathrm{pH}$ of the feed to the 200 Areas Effluent Treatment Facility. Each basin has a capacity of 24.6 million liters ( 6.5 million gallons). Spare capacity equal to the volume of one basin is reserved as contingency in the event a leak develops in an operational basin. The basins are constructed of two, flexible, highdensity, polyethylene membrane liners. A system is provided to detect, collect, and remove leachate from between the primary and secondary liners. Beneath the secondary liner is a 0.9-meter(3.0-feet-) thick soil/bentonite barrier should the primary and secondary liners fail. Each basin has a mechanically tensioned floating membrane cover constructed of very low-density polyethylene to keep out unwanted material and to minimize evaporation of the basin contents. The facility began operation in April 1994 and is designed to operate for 20 years. A total of 5.3 million liters (1.4 million gallons) of process condensate was stored in the basins at the end of 1996 .

\section{Areas Effluent Treatment Facility}

The 200 Areas Effluent Treatment Facility (near the 200-East Area) provides for 1) collection of liquid effluents, 2) a treatment system to reduce concentrations of radioactive and hazardous waste constituents in the effluent streams to acceptable levels, 3) tanks to allow for verification of treated effluent characteristics before discharge, and 4) a stateapproved land disposal structure for effluent disposal. The treatment process constitutes best available technology and includes filtration, ultraviolet light/peroxide destruction of organic compounds, reverse osmosis to remove dissolved solids, and ion exchange to remove the last traces of contaminants. Treatment capacity of the facility is 570 liters per minute (150 gallons per minute). The facility began operation in December 1995 and has a 30-year design life. Approximately 37.5 million liters ( 9.9 million gallons) of waste water were treated in 1996.

The treated effluent from this facility is sampled to verify that the concentrations of radioactive and hazardous waste constituents have been reduced to acceptable levels, then discharged via a dedicated pipeline to a state-approved land disposal structure. The disposal facility (200-West Area) consists of an underground drain field. The percolation rates for the field have been established by site testing and evaluation of soil characteristics. Tritium in the liquid effluent cannot be practically removed, and the location of the disposal facility 


\section{Hanford Site}

maximizes the time for migration to the Columbia River to allow for radioactive decay. A delisting petition was approved by the EPA that exempts the treated process condensate from the requirements of dangerous waste regulations under the Resource Conservation and Recovery Act and imposes certain effluent quality restrictions. High concentrations of ammonia in the process condensate also make this feed stream a dangerous waste subject to WAC 173-303. After treatment in the facility, the discharged effluent is not a dangerous waste. The disposal facility was permitted in June 1995 by the Washington State Department of Ecology under WAC 173-216. The discharge permit requires monitoring of the effluent groundwater to ensure that concentrations for certain constituents are not exceeded.

Secondary waste from treating the process condensate is a low-level mixed waste that will be concentrated, dried, and packaged in 208-liter (55-gallon) drums. The 200 Area!s Effluent Treatment Facility is a Resource Conservation and Recovery Act-permitted storage facility, and this secondary waste material is temporarily stored until it is transferred to the Central Waste Complex for subsequent treatment (if needed to meet land disposal restriction treatment standards) and disposal in mixed waste trench $218-W-5$ in the 200-West Area.

\section{Areas Treated Effluent Disposal Facility}

The 200 Areas Treated Effluent Disposal Facility is a collection and disposal system for non-Resource Conservation and Recovery Act-permitted waste streams that already meet discharge requirements. Implementation of regulatory required "best available technology/all known and reasonable treatment" is the responsibility of the generating facilities. Facilities that discharge to this facility currently include the Plutonium Finishing Plant, 222-S Laboratory, T Plant, 284-W Power Plant, Plutonium-Uranium Extraction Plant, B Plant, and 242-A-81 Water Services Building. Each facility must comply with discharge limits in WAC 173-216 without further treatment.

This facility began operation in April 1995 and is designed to operate for 30 years. The design capacity of the facility is 8,700 liters per minute $(2,300$ gallons per minute), though the discharge permit presently limits the average monthly flow to 2,400 liters per minute ( 640 gallons per minute). Approximately 760 million liters (200 million gallons) of treated effluent were discharged in 1996. The effluent is discharged to two 2-hectare (5-acre) disposal ponds located east of the 200-East Area. The discharge permit requires monitoring of the effluent groundwater to ensure that concentrations for certain constituents are not exceeded.

\section{Area Treated Effluent Disposal Facility}

Waste water from laboratories, research facilities, office buildings, and former fuel fabrication facilities in the 300 Area is treated in the 300 Area Treated Effluent Disposal Facility. The waste water consists of once-through cooling water, steam condensate, and other liquid wastes generated in noncontact radioactive processes. The laboratory services are particularly critical to Hanford Site cleanup activities, including tank waste remediation efforts.

This facility is designed for continuous receipt of waste waters, with a storage capacity of up to 5 days at the design flow rate of 1,100 liters per minute ( 300 gallons per minute). The facility treats 


\section{Environmental Report 1996 Summary}

the waste water using best available technology. The treatment process includes iron coprecipitation to remove heavy metals, resin ion exchange to remove mercury, and ultraviolet light/hydrogen peroxide oxidation to destroy organics and cyanide. Sludge from the iron coprecipitation process is dewatered and used for backfill. The treated liquid effluent is monitored and discharged through an outfall to the Columbia River under a National Pollutant Discharge Elimination System permit. Capability exists to divert the treated effluent to holding tanks before discharge, if needed, until a determination can be made for final disposal based on sampling. This facility began operating in December 1994 and treated approximately 350 million liters (92 million gallons) of waste water in 1996.

\section{Waste Handling Facility}

The 340 Waste Handling Facility provides receipt, storage, and loadout capability for low-level liquid waste generated during laboratory operations in the 300 Area. The waste is accumulated and stored in two 57,000-liter (15,000-gallon) tanks located in a covered, below-grade vault in the 340 Building. Six additional 30,000-liter (8,000-gallon) tanks in the adjacent 340-A Building provide backup storage capability. The accumulated waste is pumped into railcars and transported to the 200-East Area 204-AR Unloading Facility for neutralization and transfer to double-shell tanks for storage. The 340 facility does not have a Resource Conservation and Recovery Act permit for storage; therefore, wastes cannot be stored for more than 90 days.

The 340 facility will cease receiving waste in September 1998. A new waste handling facility with storage and truck loadout capability will be provided. The 340 facility will then be cleaned, decontaminated, and decommissioned.

\section{Area Process Sewer Upgrades}

Upgrades to the 300 Area process sewer system were completed in 1996. A proposal to reline the existing piping was approved by the regulators. The process involved camera surveillance and cleanout of the piping, installation of resinimpregnated polyester felt fiber in the pipe walls, and thermal curing by heating the water. Lateral pipelines were cut using robotics, and new access holes and cleanouts were constructed as needed. Additional process sewer lines and storm-water connections were installed. The existing pump station, which serves buildings in the southeastern 300 Area, was refurbished. Drummed residue from pipe cleanout was sent to disposal.

The process sewer system collects cooling water, steam condensate, and other liquid effluents generated in 300 Area laboratories, research facilities, and office buildings. The waste water is treated in the 300 Area Treated Effluent Disposal Facility.

\section{Phase II Liquid Effluent Streams}

DOE has committed to implement "best available technology/all known and reasonable treatment" for nine waste-water streams and to permit the streams under WAC 173-216 by October 1997. This activity is required by the Washington State Department of Ecology Consent Order \#DE 91NM-177 and Tri-Party Agreement Milestone $M-17-00 B$ and includes the elimination, minimization, or treatment of effluents being discharged to the 216-B-3 Expansion Ponds in the 200-East Area. 


\section{Hanford Site}

Project W-252, "Phase II Effluent Treatment and Disposal," will connect the following streams to the 200 Areas Treated Effluent Disposal Facility: 242-A Evaporator cooling water, 242-A Evaporator steam condensate, 284-E Power Plant waste water (including 282-E and 283-E), and B Plant/Waste Encapsulation Storage Facility cooling water. Another stream, the 241-A Tank Farm cooling water, is to be connected to the 200 Areas Treated Effluent Disposal Facility as part of Project W-030. Construction on Project W-252 is scheduled to be completed in April 1997 and startup is planned for June 1997. A supplemental discharge permit application was submitted in November 1996 so that additional streams can be disposed of to the 200 Areas Treated Effluent Disposal Facility. The permitted capacity of the facility will increase to a total average yearly flow rate of 4,540 liters per minute $(1,200$ gallons per minute) and a total average monthly flow rate of 12,900 liters per minute (3,400 gallons per minute).

\section{Miscellaneous Streams}

Miscellaneous streams are lower priority wastewater streams that discharge to the soil column throughout the Hanford Site and are subject to requirements in Washington State Department of Ecology Consent Order \#DE 91NM-177. The Plan and Schedule for Disposition and Regulatory Compliance for Miscellaneous Streams was approved by the Washington State Department of Ecology in February 1995. This document provides a plan and schedule for ensuring that miscellaneous streams will be in compliance with the applicable state regulations (e.g., WAC 173-216 and 173-218). The commitments established in the plan and schedule include annually updating the miscellaneous streams inventory (through 1998), registering injection wells, submitting categorical permit applications, and implementing best management practices.

The inventory of miscellaneous streams includes more than 640 streams. Streams that already have discharge permits in place, streams for which permit applications have been submitted, or streams that are covered under a National Pollutant Discharge Elimination System permit are not included. All injection wells were registered under WAC 173-218 in August 1995, including injection wells that were previously registered. This ensured that the registrations were current, complete, and in the same format.

Use of categorical permits provides a vehicle to easily permit miscellaneous streams with similar characteristics. Categorical permit applications are to be submitted for the following:

- hydrotesting, maintenance, and construction discharges (application submitted November 1995)

- cooling water discharges and uncontaminated steam condensate (application submitted September 1996)

- storm-water discharges.

Another categorical permit was planned for surfacewater and safety shower discharges. These streams will be included in an existing permit or eliminated. $A$ best management practices report was submitted to the Washington State Department of Ecology in August 1996 and included recommendations of preferred options and an implementation schedule. 


\section{Environmental Report 1996 Summary}

\section{Revegetation and Mitigation Planning}

DOE and the Hanford Natural Resource Trustees are working cooperatively to plan and provide effective input to restoration and mitigation for proposed remediation sites. Revegetation/mitigation plans will include the use of native plant species (seeds and shrubs) as appropriate to restore the areas disturbed by remediation activities.

The Hanford Site Biological Resources Management Plan was developed to provide DOE and its contractors with a consistent approach to protect biological resources and monitor, assess, and mitigate impacts to them from site development and environmental cleanup and restoration activities (Figure 7). This comprehensive plan provides a framework to enable Hanford Site resource professionals to effectively fulfill their responsibilities and address tribal, resource agency, and other stakeholder concerns about the site's biological resources. The policies and guidelines described in the plan were developed based on legal requirements and policy initiatives that direct an ecosystem management approach toward resources management.

The Hanford Site Biological Resources Mitigation Strategy, part of the broader biological resource policy contained in the biological resources management plan, is designed to aid DOE in balancing its primary missions of waste cleanup, technology development, and economic diversification with its stewardship responsibilities for the biological resources it administers.

This biological resources mitigation strategy will help to ensure consistent and effective implementation of mitigation recommendations and requirements, ensure mitigation measures for biological resources meet the responsibilities of DOE under the law, enable Hanford Site development and cleanup projects to anticipate and plan for mitigation needs via early identification of mitigation requirements, and provide guidance to Hanford personnel in implementing mitigation in a costeffective and timely manner.

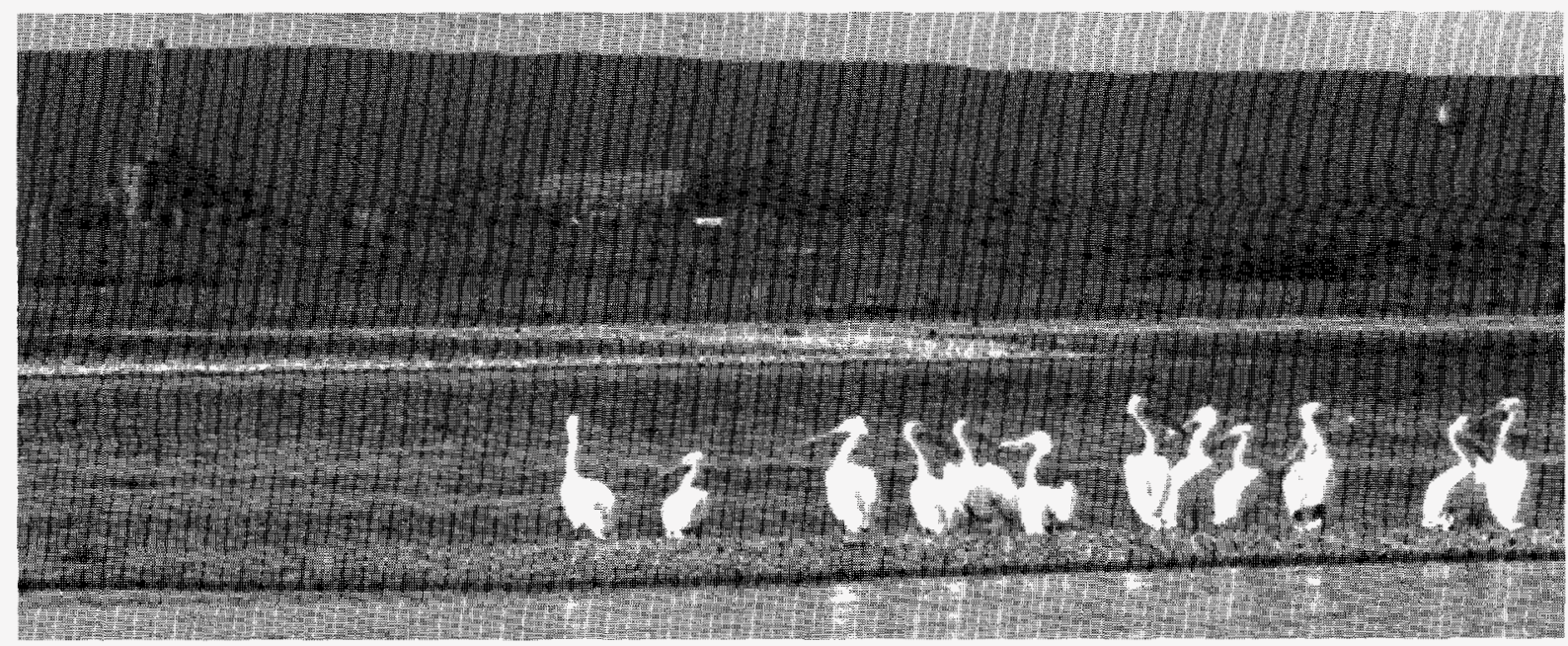

Figure 7. American white pelicans found on the Hanford Site are listed as an endangered species in the state of Washington. 


\section{Hanford Site}

\section{Compliance with Environmental Regulations}

DOE Order 5400.1, "General Environmental Protection Program," describes the environmental standards and regulations applicable at DOE facilities. These environmental standards and regulations fall into three categories: 1) DOE directives; 2) federal legislation and executive orders; and 3) state and local statutes, regulations, and requirements. The following subsections summarize the status of Hanford's compliance with these applicable regulations and list environmental occurrences for 1996.

\section{Comprehensive Environmental Response, Compensation, and Liability Act}

This Act established a program to ensure that sites contaminated by hazardous substances are cleaned up by responsible parties or the government. The Act primarily covers waste cleanup of inactive sites.

Preliminary assessments conducted for the Hanford Site revealed approximately 2,200 known individual waste sites where hazardous substances may have been disposed of in a manner that requires further evaluation to determine impact to the environment.

The DOE is actively pursuing the remedial investigation/feasibility study process at some operable units on the Hanford Site. The operable units currently being studied were selected as a result of Tri-Party Agreement negotiations.

In 1996, the Hanford Site was in compliance with requirements of the Comprehensive Environmental Response, Compensation, and Liability Act.
Cleanup is under way at various sites in the 100 , 200, and other areas. Full-scale remediation of waste sites began in the 100 Areas in 1996. The Environmental Restoration Disposal Facility, a central disposal site for contaminated soil generated during cleanup, opened in the 600 Area in 1996.

\section{Emergency Planning and Community Right-To-Know Act}

This Act requires that the public be provided with information about hazardous chemicals in the community and establishes emergency planning and notification procedures to protect the public from a release. The Act calls for creation of state emergency response commissions to guide planning for chemical emergencies. State commissions have also created local emergency planning committees to ensure community participation and planning.

To provide the public with the basis for emergency planning, the Act contains requirements for periodic reporting on hazardous chemicals stored and/or used near the community. The 1996 Hanford Site's emergency and hazardous chemical inventory was issued to the State Emergency Response Commission, local county emergency management committees, and local fire departments in March 1997. The inventory report contained information on hazardous materials in storage across the site. A toxic chemical release inventory report was issued in August 1996, which provided details regarding releases, offsite transfers, and source reduction activities involving ethylene glycol, the sole toxic chemical used in excess of regulatory thresholds 


\section{Environmental Report 1996 Summary}

during 1995. No such reporting thresholds were exceeded in 1996. During 1996, the Hanford Site was in compliance with the reporting and notification requirements contained in this Act.

\section{Resource Conservation and Recovery Act}

This Act establishes regulatory standards for the generation, transportation, storage, treatment, and disposal of hazardous wastes. The Washington State Department of Ecology has been authorized by the EPA to implement its dangerous waste program in lieu of the EPA for Washington State, except for some provisions of the hazardous and solid waste amendments of 1984 . The Washington State Department of Ecology implements the state's regulations, which are often more stringent. The Act primarily covers ongoing waste management at active facilities.

At the Hanford Site, over 60 treatment, storage, and disposal units have been identified that must be permitted or closed in accordance with the Act and Washington State regulations. These units are required to operate under the Washington State Department of Ecology's interim-status compliance requirements. Approximately one-half of the units will be closed.

Subtitle I of the Resource Conservation and Recovery Act deals with regulation of underground storage tank systems. These regulations were added to the Act by the hazardous and solid waste amendments of 1984. The EPA has developed regulations implementing technical standards for tank performance and management, including standards governing the cleanup and closure of leaking tanks. These regulations do not apply to the single- and double-shell tanks, which are regulated as treatment, storage, and disposal facilities.

\section{Clean Air Act}

The purpose of this Act is to protect public health and welfare by safeguarding air quality, bringing polluted air into compliance, and protecting clean air from degradation. In Washington State, the provisions of the Act are implemented by EPA, Washington State Department of Ecology, Washington State Department of Health, and local air authorities.

Washington State regulations require applicable controls and annual reporting of all radioactive air emissions. The Hanford Site operates under a license for such emissions. The conditions specified in the license will be incorporated into the Hanford Site air operating permit, scheduled to be issued in 1997.

Revised Clean Air Act requirements for radioactive air emissions were issued in December 1989. Emissions from the Hanford Site are within the state and EPA offsite emissions standard of $10 \mathrm{mil}-$ lirem per year. Nearly all Hanford Site sources currently meet the procedural requirements for flow measurement, emissions measurement, quality assurance, and sampling documentation.

The local air authority (the Benton County Clean Air Authority) regulations pertain to detrimental effects, fugitive dust, open burning, odor, opacity, and asbestos handling. The Authority has also been delegated responsibility to enforce the EPA asbestos regulations under the revised Clean Air Act. The site remains in compliance with the regulations. 


\section{Hanford Site}

\section{Clean Water Act}

This Act applies to point discharges to waters of the United States. At the Hanford Site, the regulations are applied through National Pollutant Discharge Elimination System permits that govern effluent discharges to the Columbia River. The permits specify discharge points (called outfalls), effluent limitations, and monitoring requirements. Several permit exceedences occurred at the 300 Area Treated Effluent Disposal Facility in 1996 despite the use of the best available technology. Preparations for a modification to the facility's discharge permit are under way.

\section{Safe Drinking Water Act}

The National Primary Drinking Water Regulations of the Safe Drinking Water Act apply to the drinking water supplies at the Hanford Site. These regulations are enforced by the Washington State Department of Health. In 1996, all Hanford Site water systems were in compliance with requirements and agreements.

\section{Toxic Substances Control Act}

The application of Toxic Substances Control Act requirements to the Hanford Site essentially involves regulation of the chemicals called polychlorinated biphenyls. The site is currently in compliance with regulations for nonradioactive polychlorinated biphenyls. All radioactive polychlorinated biphenyl wastes are being stored pending development of treatment and disposal technologies and capabilities.

\section{Federal Insecticide, Fungicide, and Rodenticide Act}

The EPA is responsible for ensuring that a chemical, when used according to label instructions, will not present unreasonable risks to human health or the environment. This Act and specific chapters of the Revised Code of Washington apply to storage and use of pesticides. In 1996, the Hanford Site was in compliance with these requirements.

\section{Endangered Species Act}

Many rare species of native plants and animals are known to occur on the Hanford Site. Two of these (bald eagle and peregrine falcon) are listed by the U.S. Fish and Wildlife Service as endangered or threatened. Others are listed by the Washington State Department of Fish and Wildlife as endangered, threatened, or sensitive species. Hanford Site activities complied with the Endangered Species Act in 1996.

National Historic Preservation Act, Archaeological Resources Protection Act, Native American Graves Protection and Repatriation Act, and American Indian Religious Freedom Act

Cultural resources on the Hanford Site are subject to the provisions of these Acts (Figure 8). In 1996, the Hanford Site was in compliance with these Acts. 


\section{Environmental Report 1996 Summary}

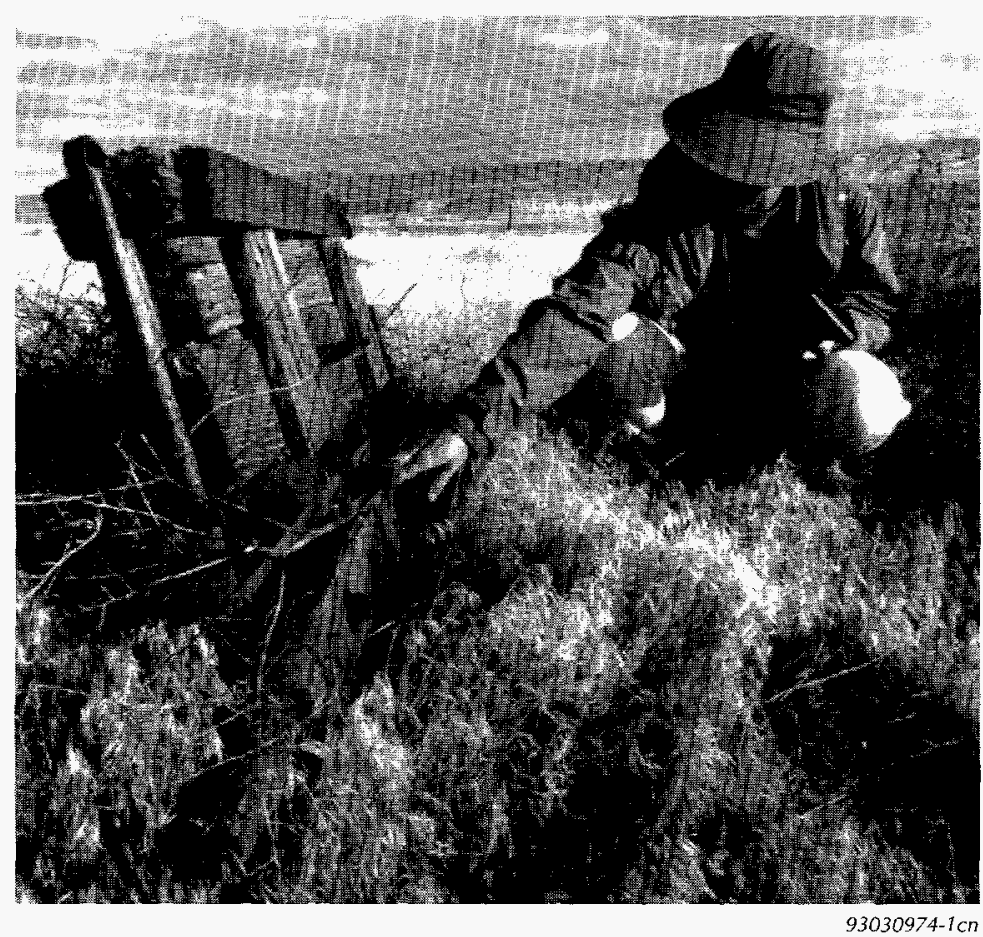

Figure 8. Cultural resources reviews are conducted to ensure compliance with federal acts.

\section{National Environmental Policy Act Environmental Occurrences}

This Act establishes environmental policy to prevent or eliminate damage to the environment and to enrich our understanding of ecological systems and natural resources. This Act requires that major federal projects with significant impacts be carefully reviewed and reported to the public in environmental impact statements. Other documents such as environmental assessments are also prepared in accordance with requirements of the Act.

Several environmental impact statements related to programs or activities on the Hanford Site are in process or in the planning stage.
Onsite and offsite environmental occurrences (spills, leaks, etc.) of radioactive and nonradioactive effluent materials during 1996 were reported to DOE and other federal and state agencies as required by law. All emergency, unusual, and off-normal occurrence reports, including event descriptions and corrective actions, are available for review in the DOE Hanford Reading Room located on the campus of Washington State University at Tri-Cities, Richland, Washington. There were no emergency occurrence or environmentally significant unusual occurrence reports filed in 1996. There were 15 off-normal environmental release-related occurrence reports filed during 1996. 


\section{Hanford Site}

\section{Environmental Monitoring Information}

Environmental monitoring of the Hanford Site consists of 1) effluent monitoring, and 2) environmental surveillance, including groundwater monitoring. Effluent monitoring is performed as appropriate by the operators at the facility or at the point of release to the environment. Additional monitoring is conducted in the environment near facilities that discharge, or have discharged, effluents. Environmental surveillance consists of sampling and analyzing environmental media on and off the site to detect and quantify potential contaminants and to assess their environmental and human health significance.

The overall objectives of the monitoring and surveillance programs are to demonstrate compliance with applicable federal, state, and local regulations; confirm adherence to DOE environmental protection policies; and support environmental management decisions.

\section{Effluent Monitoring}

Effluent monitoring includes facility effluent monitoring (monitoring effluents at the point of release to the environment) and near-facility environmental monitoring (monitoring the environment near operating facilities).

\section{Facility Effluent Monitoring}

Liquid and gaseous effluents that may contain radioactive and hazardous constituents are continually monitored at the Hanford Site. Facility operators monitor effluents mainly through analyzing samples collected near points of release into the environment. Effluent monitoring data are evaluated to determine their degree of compliance with applicable federal, state, and local regulations and permits.

Measuring devices are used to quantify most facility effluent flows, with a smaller number of flows calculated using process information. Liquid and gaseous effluents with a potential to contain radioactivity at prescribed threshold levels are monitored for total alpha and total beta activity and, as warranted, specific gamma-emitting radionuclides. Nonradioactive hazardous constituents are also monitored, as applicable.

Radioactive effluents from many onsite facilities are approaching levels practically indistinguishable from the naturally occurring radioactivity present everywhere. This decrease translates to a very small offsite radiation dose attributable to site activities. The new site mission of environmental restoration rather than nuclear materials production is largely responsible for this trend. Consistent with these conditions of diminishing releases, totals of radionuclides in effluents released at the site in 1996 are not significantly different from totals in 1995.

\section{Near-Facility Environmental Monitoring}

The near-facility environmental monitoring program is designed to protect the environment adjacent to facilities and ensure compliance with federal, state, and local regulations. Specifically, in 1996, this program monitored new and existing sites, processes, and facilities for potential impacts and releases; fugitive emissions and diffuse sources from contaminated areas; and surplus facilities 


\section{Environmental Report 1996 Summary}

before decontamination or decommissioning. Air, surface water and springs, surface contamination, vadose zone monitoring, soil and vegetation, external radiation, and investigative sampling (which can include wildlife) were sampled. Some parameters typically monitored are $\mathrm{pH}$, radionuclide concentrations, radiation exposure levels, and concentrations of selected hazardous chemicals. Samples are collected from known or expected effluent pathways. These pathways are generally downwind of potential or actual airborne releases and downgradient of liquid discharges.

Near-Facility Air Monitoring. Radioactivity in air was sampled by a network of continuously operating samplers at 58 locations near nuclear facilities: 4 located in the 100-N Area, 4 in the 100-K Area, 38 in the 200 Areas, 3 at the Environmental Restoration Disposal Facility, 4 at the 100-D,DR Area, 3 at the 100-B,C Area, 1 near the 300 Area Treated Effluent Disposal Facility, and 1 collocated with samplers operated by the Pacific Northwest National Laboratory and the Washington State Department of Health at the Wye Barricade. Air samplers were primarily located within approximately 500 meters $(1,500$ feet $)$ of sites and/or facilities having the potential for, or history of, environmental releases, with an emphasis on the prevailing downwind directions. Of the radionuclide analyses performed, strontium-90, cesium-137, plutonium-239,240, and uranium were consistently detectable in the $100-\mathrm{N}$ and 200 Areas. Cobalt- 60 was consistently detectable in the 100-N Area. Air concentrations for these radionuclides were elevated near facilities compared to the concentrations measured offsite by Pacific Northwest National Laboratory.

\section{Surface-Water Disposal Units and 100-N Springs} Monitoring. Samples collected from surface-water disposal units included water, sediment, and aquatic vegetation. Only water samples were taken at $100-\mathrm{N}$ shoreline springs. Radiological analyses of water samples from surface-water disposal units included strontium-90, plutonium-238, plutonium-239,240, uranium, tritium, and gammaemitting radionuclides. Radiological analyses of sediment and aquatic vegetation samples were performed for strontium-90, plutonium-239,240, uranium, and gamma-emitting radionuclides (Figure 9). Nonradiological analyses were performed for $\mathrm{pH}$, temperature, and nitrates.

Radiological analytical results for liquid samples from surface-water disposal units (i.e., ponds and ditches) located in the 200 Areas were less than the DOE-derived concentration guides, and in most cases, were equal to or less than the analytical detection limits. Although some elevated levels were seen in both aquatic vegetation and sediment, in all cases, the radiological analytical results were much less than the standards used for radiological control. The results for $\mathrm{pH}$ were well within the 2.0 to $12.5 \mathrm{pH}$ standard for liquid effluent discharges based on the discharge limits listed in the Resource Conservation and Recovery Act. The analytical results for nitrates were all less than the

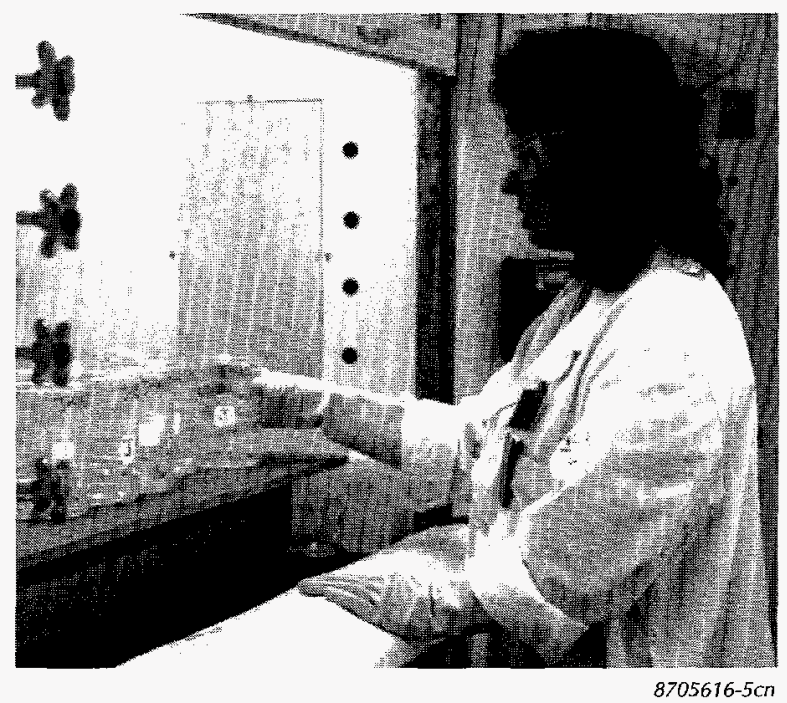

Figure 9. Thousands of environmental samples are analyzed annually. 


\section{Hanford Site}

45-milligram per liter EPA drinking water standard for public water supplies.

Groundwater springs along the 100-N Area shoreline are sampled annually to verify the reported radionuclide releases to the Columbia River from past N Reactor operations. By characterizing the radionuclide concentrations in the springs along the shoreline, the results can be compared to the concentrations measured at the facility effluent monitoring well. In 1996, the concentrations detected in shoreline springs samples were highest in springs nearest the effluent monitoring well.

Near-Facility Radiological Surveys. In 1996, there were approximately 4,016 hectares $(9,923$ acres $)$ of posted outdoor contamination areas and 1,025 hectares (2,532 acres) of posted underground radioactive materials areas, not including active facilities, at the Hanford Site. These areas were typically associated with burial grounds, covered ditches, cribs, and tank farms. The posted contamination areas vary between years because of an ongoing effort to clean, stabilize, and remediate areas of known contamination. During this time, new areas of contamination were being identified. It was estimated that the external dose rate at $80 \%$ of the identified outdoor contamination areas was less than 1 millirem per hour measured at 1 meter (3.28 feet), though direct dose rate readings from isolated radioactive specks (a diameter less than 0.6 centimeter [0.25 inch]) could have been considerably higher. Contamination levels of this magnitude did not significantly add to dose rates for the public or Hanford Site workers in 1996.

Vadose Zone Monitoring. The inactive liquid effluent facilities vadose zone monitoring program tracks the movement of radioactive contaminants that were discharged to the soil. There are over
300 liquid waste disposal sites at Hanford that have received over 53 billion liters ( 14 billion gallons) of waste, excluding the 1,620 billion liters (430 billion gallons) that were discharged at the surface to ponds and ditches. During 1996, approximately 70 boreholes were logged around these facilities for radioactive plume identification and tracking. In addition, approximately 35 wells scheduled for decommissioning onsite were surveyed for gamma-ray radiation to ensure the wells were not contaminated and for moisture and geologic data to help determine moisture migration pathways. The environmental restoration program also was supported by the collection of approximately 40 borehole logs for delineating subsurface radioactive contamination.

\section{Soil and Vegetation Sampling from Operational}

Areas. Soil and vegetation samples were collected on or adjacent to waste disposal units and from locations downwind and near or within the boundaries of the operating facilities. Samples were collected to detect potential migration and deposition of facility effluents. Special samples were also taken where physical or biological transport problems were identified. Migration can occur as the result of resuspension from radioactively contaminated surface areas, absorption of radionuclides by the roots of vegetation growing on or near underground and surface-water disposal units, or by waste site intrusion by animals. Soil and vegetation sample concentrations for some radionuclides were elevated near facilities when compared to concentrations measured offsite. The concentrations show a large degree of variance; in general, samples collected on or adjacent to waste disposal facilities had significantly higher concentrations than those collected farther away. The number of sampling locations at the 100-N Area was reduced by approximately $50 \%$ in 1996 . 


\section{Environmental Report 1996 Summary}

Near-Facility External Radiation. External radiation fields were measured near facilities and waste handling, storage, and disposal sites to measure, assess, and control the impacts of operations.

A hand-held micro-rem meter (to measure lowlevel radiation exposure) was used to survey points along the N Springs area (Figure 10). The radiation rates measured in the $\mathrm{N}$ Springs area continued to decline in 1996, reflecting discontinued discharges to the 1301-N Liquid Waste Disposal Facility and the continuing decay of its radionuclide inventory.

The 1996 thermoluminescent dosimeter results indicate that direct radiation levels are highest near facilities that had contained or received liquid effluent from $\mathrm{N}$ Reactor. These facilities primarily include the 1301-N and 1325-N Liquid Waste Disposal Facilities. Because the results for these two facilities were noticeably higher than those for other 100-N Area thermoluminescent dosimeter locations, they were approximately $9 \%$ lower than exposure levels measured at these locations in 1995.

This is the fourth year that thermoluminescent dosimeters have been placed in the 100-K Area, surrounding the 105-K East and 105-K West Fuel Storage Basins and adjacent reactor buildings. Three of the thermoluminescent dosimeters have consistently shown elevated readings as a result of their proximity to radioactive waste storage areas or stored radioactive rail equipment.

Five new thermoluminescent dosimeter locations were established in the 100-D,DR Area during the fourth quarter of 1996 to evaluate environmental restoration activities at the 116-D-7 and 116-DR-9 Liquid Waste Disposal Facilities. Although no comparative data are available because of the recent placement of these dosimeters, the fourth quarter analyses indicate readings comparable to offsite background levels.

The highest dose rates in the 200/600 Areas were measured near waste handling facilities such as tank farms. The highest dose rate was measured at the 241-A Tank Farm complex located in the 200-East Area. The average annual dose rate measured in 1996 by thermoluminescent dosimeters was 120 millirem per year, which equaled the average dose rate measured in 1995.

Two new thermoluminescent dosimeter locations were established at the Environmental Restoration Disposal Facility during the fourth quarter of 1996 to evaluate the disposal activities currently in progress. Although no comparative data are available because of the recent placement of these dosimeters, the fourth quarter analyses indicate readings comparable to offsite background levels.

The highest dose rates in the 300 Area were measured near waste handling facilities such as the 340 Waste Handling Facility. The average annual dose rate measured in the 300 Area in 1996 was 120 millirem per year. This represents a decrease of $14 \%$ compared to the average dose rate of 140 millirem per year measured in 1995 . The average annual dose rate at the 300 Area Treated Effluent Disposal Facility in 1996 was 85 millirem per year, which represents an increase of $5 \%$ compared to the average dose rate of 81 millirem per year measured in 1995.

The average annual dose rate measured in the 400 Area in 1996 was 83 millirem per year, which represents an increase of $8 \%$ compared to the average dose rate of 77 millirem per year measured in 1995. 


\section{Hanford Site}

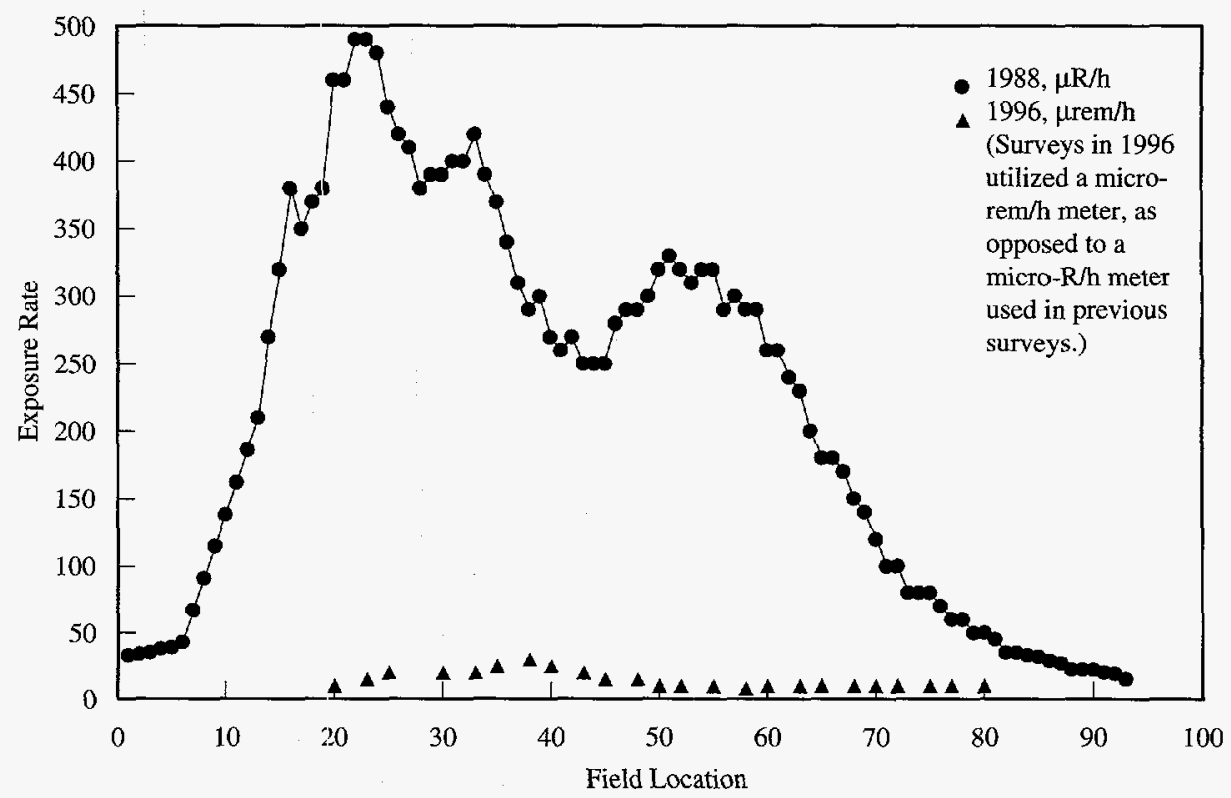

SG97030269.72a

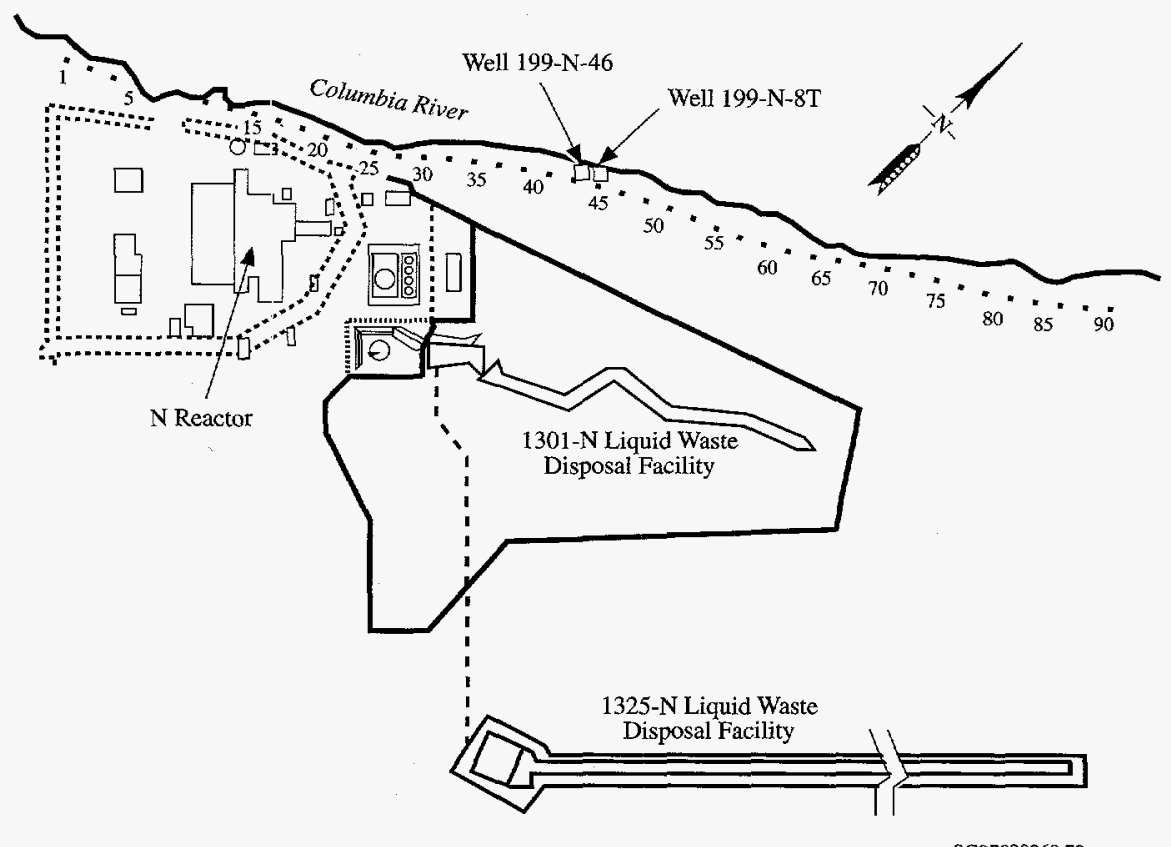

SG97030269.72

Figure 10. Radiation survey measurements are conducted along the 100-N Area shoreline. This figure compares results from 1988 and 1996. 


\section{Environmental Report 1996 Summary}

Investigative Sampling. Investigative sampling was conducted in the operations areas to confirm the absence or presence of radioactive or hazardous contaminants. Investigative sampling took place near facilities such as storage and disposal sites for at least one of the following reasons:

- to follow-up radiological surface surveys that indicated radioactive contamination was present

- to conduct preoperational surveys that quantified the radiological/hazardous conditions at a site before facility construction or operation

- to quantify the radiological condition of a site before remediation

- to determine if biotic intrusion (e.g., animal burrows or deep-rooted vegetation) has created a potential for the spread of contaminants

- to determine the integrity of waste containment systems.

\section{Environmental Surveillance}

Environmental surveillance of the Hanford Site and the surrounding region is conducted to demonstrate compliance with environmental regulations, confirm adherence to DOE environmental protection policies, support DOE environmental management decisions, and provide information to the public.

Environmental surveillance includes sampling environmental media on and off the Hanford Site for potential chemical and radiological contaminants originating from site operations. The media sampled in 1996 included air, surface water and sediment, drinking water, food and farm products, fish and wildlife, soil and vegetation, external radiation levels, and groundwater.

\section{Surveillance Design}

The primary pathways for movement of radioactive materials and chemicals from the site to the public are the atmosphere and surface water. Figure 11 illustrates these potential routes and exposure pathways to humans.

The significance of each pathway was determined from measurements and calculations that estimated the amount of radioactive material or chemical transported along each pathway and by comparing the concentrations or potential doses to environmental and public health protection standards or guides. Pathways were also evaluated based on prior studies and observations of radionuclide and chemical movement through the environment and food chains. Calculations based on effluent data showed the expected concentrations off the Hanford Site to be low for all Hanford-produced radionuclides and chemicals and to be frequently below the level that could be detected by monitoring technology. To ensure that radiological and chemical analyses of samples were sufficiently sensitive, minimum detectable concentrations of key radionuclides and chemicals were established at levels well below applicable health standards.

\section{Air Surveillance}

Radioactive materials in air were sampled continuously at 40 locations onsite, at the site perimeter, and in nearby and distant communities. Nine of these locations were community-operated environmental surveillance stations that were managed and operated by local school teachers (Figure 12). At all locations, particulates were filtered from the air and analyzed for radionuclides. Air was sampled 

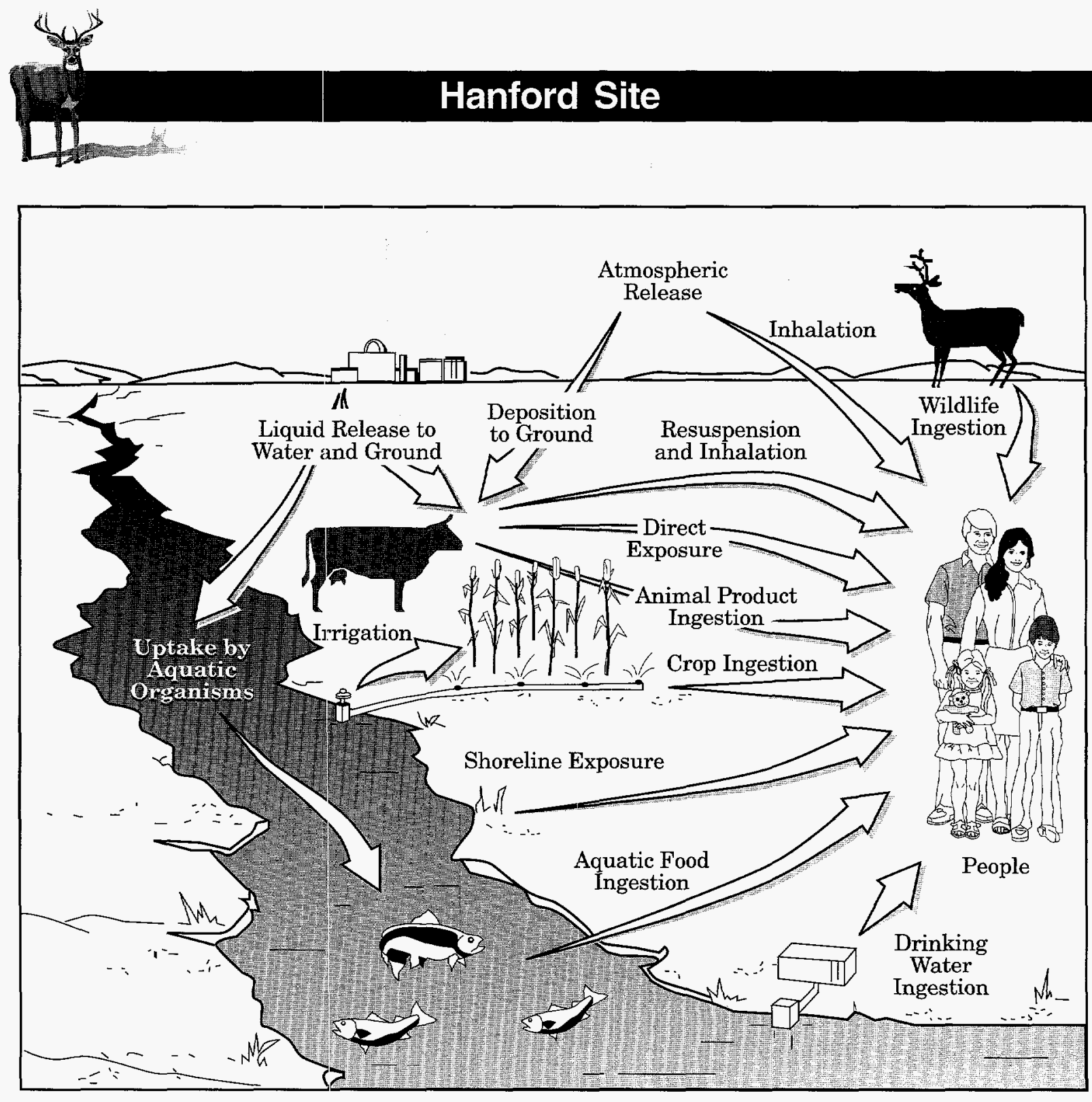

SG97030269.131C

Figure 11. The primary pathways for movement of radioactive materials and chemicals from the site to the public are the atmosphere and surface water.

and analyzed for selected gaseous radionuclides at key locations. Several radionuclides released at the site are also found worldwide from two other sources: naturally occurring radionuclides and radioactive fallout from historical nuclear activities not associated with Hanford. The potential influence of emissions from site activities on local radionuclide concentrations was evaluated by comparing differences between concentrations measured at distant locations within the region and concentrations measured at the site perimeter.

For 1996, no differences were observed between the annual average total beta air concentrations measured at the site perimeter and those measured at distant community locations. Air concentrations of total alpha were slightly elevated at the site perimeter compared to the distant stations; however, 


\section{Environmental Report 1996 Summary}

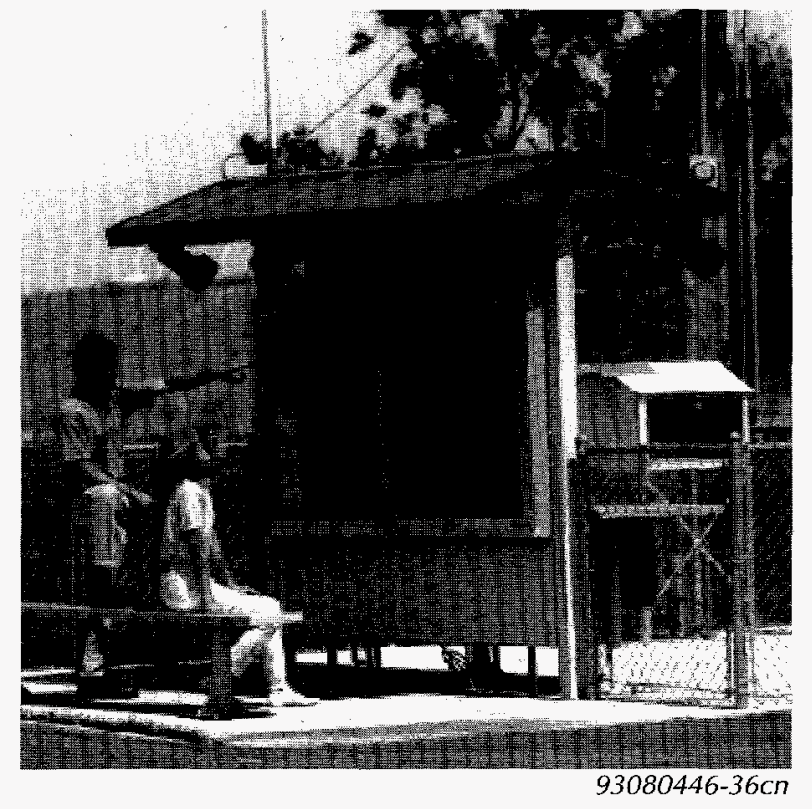

Figure 12. Local teachers participate in environmental surveillance activities at nine local community-operated environmental surveillance stations.

the concentrations were within the range of historical values. Numerous specific radionuclides in quarterly composite samples were analyzed using gamma scan analysis; however, no radionuclides of Hanford origin were detected consistently.

Tritium concentrations for 1996 were slightly elevated at the site perimeter compared to the distant station; however, the difference was not statistically significant.

lodine- 129 concentrations were statistically elevated at the site perimeter compared to the distant locations, indicating a measurable Hanford source (Figure 13); however, the average concentration at the site perimeter was only $0.000003 \%$ of the DOEderived concentration guide of 70 picocuries per cubic meter. The DOE-derived concentration guide is the air concentration that would result in a radiation dose equal to the DOE public dose limit (100 millirems per year).

Strontium-90 was detected in 8 of the 15 onsite air samples, with the maximum concentration at $0.002 \%$ of the DOE-derived concentration guide of 9 picocuries per cubic meter. Strontium-90 was also detected at three of the seven perimeter locations and at two of the six distant locations. The maximum concentration at the perimeter location was less than $0.0004 \%$ of the DOE-derived concentration guide and at the distant location less than $0.0002 \%$ of the DOE-derived concentration guide.

Plutonium-239,240 concentrations were similar for air samples collected at the site perimeter and the distant locations. The maximum plutonium-239,240 air concentration was $0.06 \%$ of the DOE-derived concentration guide of 0.02 picocuries per cubic meter.

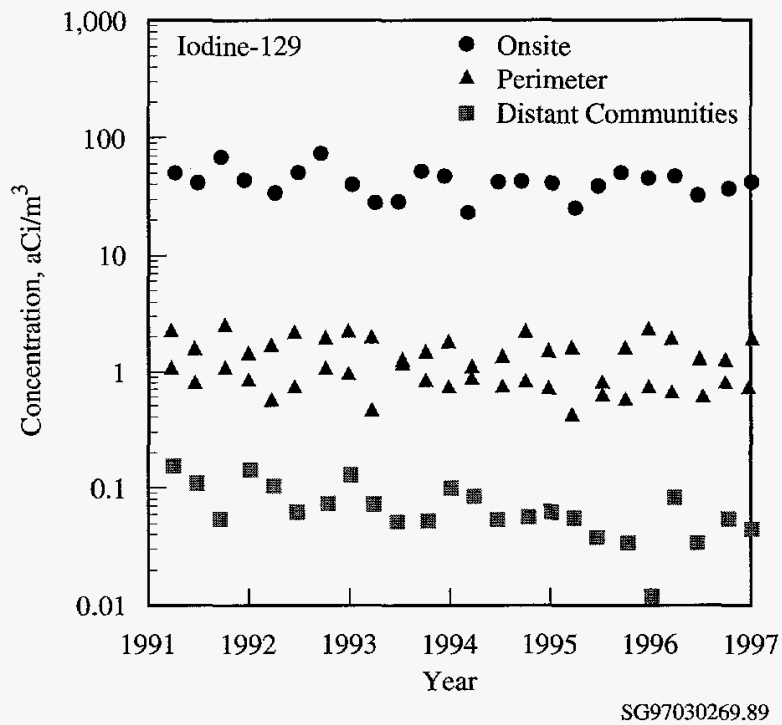

Figure 13. Concentrations of lodine-129 are measured in air. This figure shows concentrations from 1991 through 1996. 


\section{Hanford Site}

Uranium isotopic concentrations (uranium-234, uranium-235, and uranium-238) were similar onsite, at the perimeter, and at the distant locations for 1996 . The uranium concentrations were $0.03 \%$ of the 0.1-picocurie per cubic meter DOE-derived concentration guide.

No samples were collected in 1996 to test for nonradionuclides.

\section{Surface Water and Sediment Surveillance}

The Columbia River was one of the primary environmental exposure pathways to the public during 1996 as a result of past operations at the Hanford Site. Radiological and chemical contaminants entered the river along the Hanford Reach primarily through seepage of contaminated groundwater. Water samples were collected from the river at various locations throughout the year to determine compliance with applicable standards.

Although radionuclides associated with Hanford operations continued to be identified routinely in Columbia River water during the year (Figure 14),

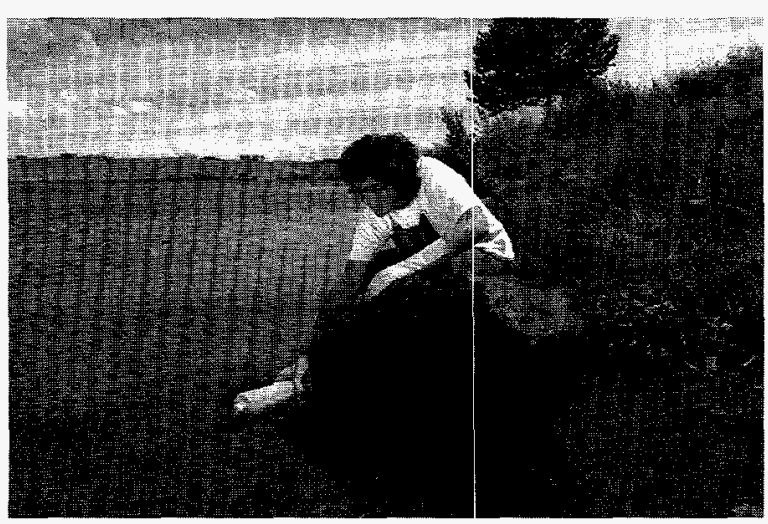

94050922-110cn

Figure 14. Water Sampling from the Columbia River Shoreline concentrations remained extremely low at all locations and were well below standards. The concentration of tritium was significantly higher ( $5 \%$ significance level) at the Richland Pumphouse (downstream from the site) than at Priest Rapids Dam (upstream from the site), indicating contribution along the Hanford Reach (Figure 15).

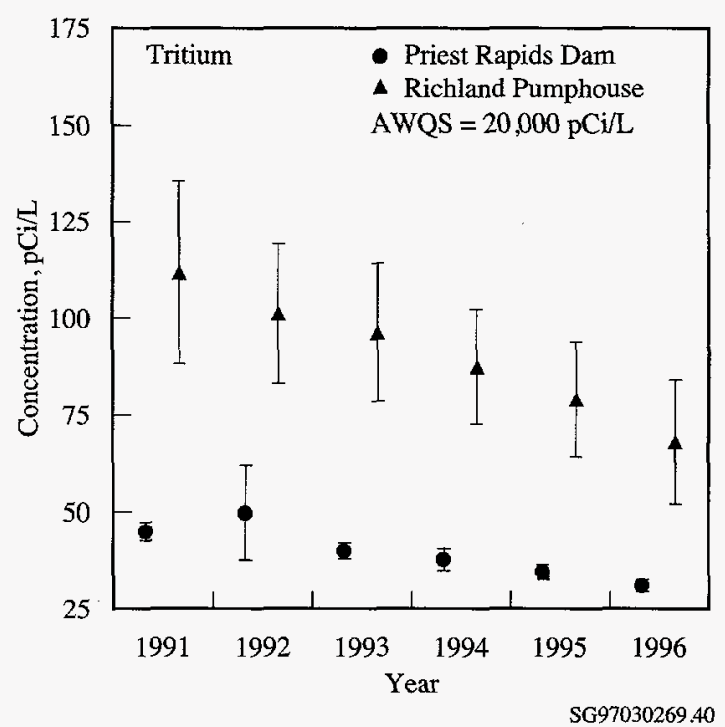

Figure 15. Annual average tritium concentrations are determined in Columbia River Water. This figure shows concentrations from 1991 through 1996. (AWQS = ambient water quality standard)

Transect sampling in 1996 revealed elevated tritium concentrations along the Benton County shoreline near the 100-N Area, Old Hanford Townsite, 300 Area, and Richland Pumphouse. Total uranium concentrations were elevated along the shorelines of both Benton and Franklin counties near the 300 Area and Richland Pumphouse. The highest total uranium concentration was measured near the Franklin County shoreline of the Richland Pumphouse transect and likely resulted from groundwater seepage and irrigation return canals on the east shore of the river. 


\section{Environmental Report 1996 Summary}

Several metals and anions were detected both upstream and downstream of the Hanford Site. Nitrate concentrations were elevated along the Franklin County shoreline of the Old Hanford Townsite, 300 Area, and Richland Pumphouse transects and likely resulted from groundwater seepage associated with extensive irrigation north and east of the Columbia River.

With the exception of aluminum, iron, and nitrate which had the higher average quarterly concentration at the Richland Pumphouse, no consistent differences were found between average quarterly contaminant concentrations in the Vernita Bridge and Richland Pumphouse transect samples. All metal and anion concentrations in Columbia River water collected in 1996 were less than Washington State ambient surface water quality criteria levels for acute toxicity, except for silver and cadmium that both exceeded the criteria for a few samples. The chronic toxicity levels for lead and selenium were occasionally exceeded in Columbia River transect samples. Volatile organic compounds (chloroform, toluene, and trichloroethylene) were occasionally detected in Columbia River water in 1996.

Samples of Columbia River surface sediments were collected in 1996 from permanently flooded monitoring sites above McNary Dam (downstream of the site), above Priest Rapids Dam (upstream of the site), and along the Hanford Reach. Strontium-90 was the only radionuclide to exhibit consistently higher median concentrations at McNary Dam compared to the other locations. The median concentration of cobalt- 60 was highest in sediment collected along the Hanford Reach. Sediment samples were also collected from five periodically inundated riverbank springs in 1996. The concentrations of radionuclides in sediment collected from riverbank springs were similar at all locations and were comparable to sediment collected behind Priest Rapids Dam.

Detectable concentrations of most metals were found in all Columbia River sediment samples with the exception of silver, which was below the detection limit for all samples. Median concentrations of most metals were highest in McNary Dam sediments. The highest median concentration of chromium was found in riverbank spring sediment.

Water samples were collected from six Columbia River shoreline springs in 1996. All radiological contaminant concentrations measured in riverbank spring water in 1996 were less than the DOEderived concentration guides. However, tritium concentrations in the 100-B Area and Old Hanford Townsite riverbank springs (Figure 16) exceeded the Washington State ambient surface water quality criteria levels. There are currently no ambient surface water quality criteria levels directly applicable to uranium. However, total uranium exceeded the site-specific proposed EPA drinking water standard in the 300 Area riverbank spring. All other radionuclides were below the Washington State ambient surface water quality criteria.

All nonradiological contaminants measured in riverbank springs located on the Hanford shoreline in 1996 were below the Washington State ambient surface water acute toxicity levels with the exception of cadmium in the 100-F Area spring; chromium(IV) in springs in the 100-B, 100-D, and 100-F Areas; and copper in the 100-F and 300 Areas springs. The Washington State ambient surface water chronic toxicity levels for cadmium, chromium, selenium, and zinc were exceeded at some locations. Riverbank spring sampling protocols do not lend themselves to a direct comparison 


\section{Hanford Site}
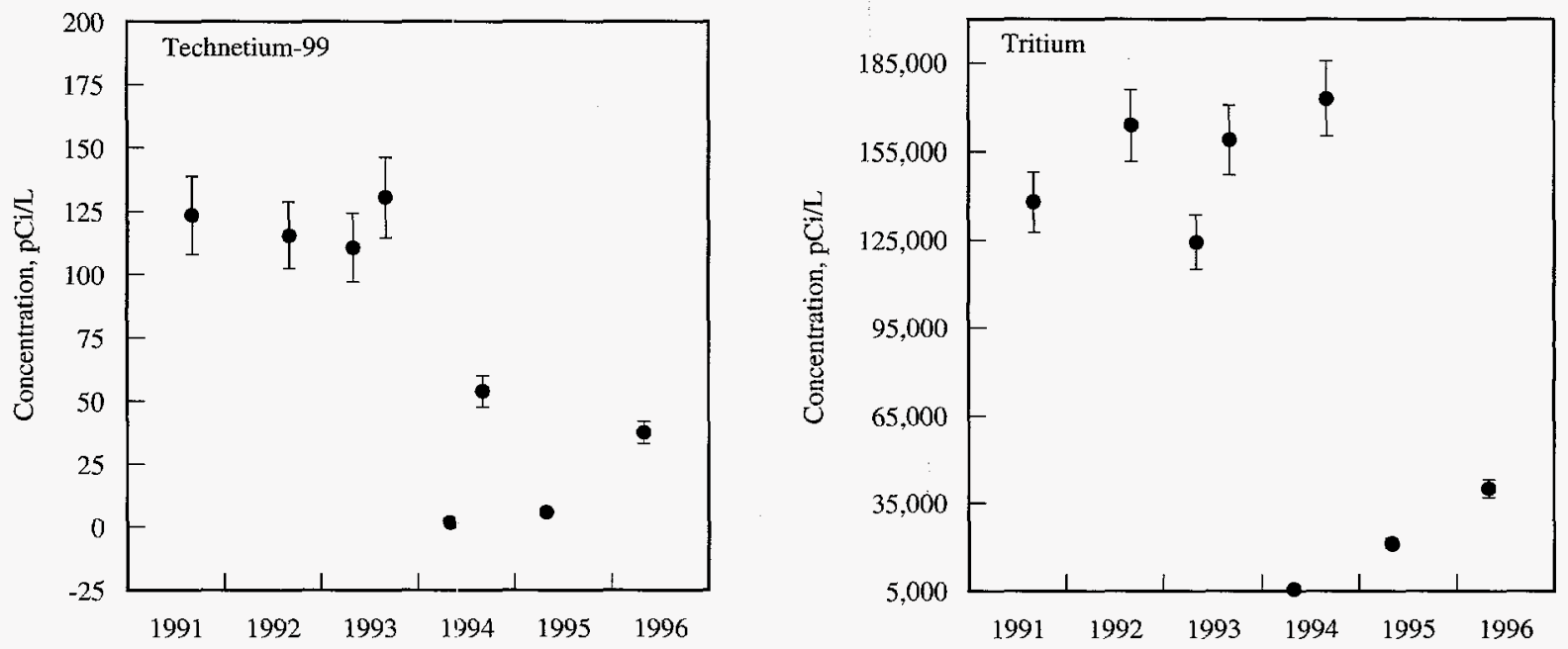

SG97030269.45

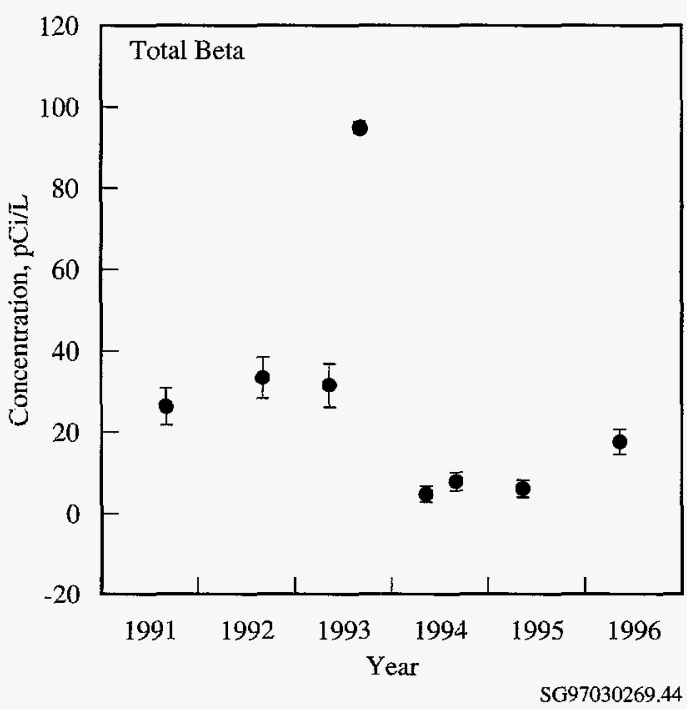

Figure 16. Concentrations (average \pm 2 total propagated analytical uncertainty) of constituents of interest are measured in riverbank spring water near the Old Hanford Townsite. This figure shows concentrations from 1991 through 1996. As a result of figure scale, some uncertainties (error bars) are concealed by the point symbol.

of most metal concentrations measured in riverbank springs to ambient surface water acute and chronic toxicity levels. The standards are used instead as a point of reference. Nitrate concentrations were the highest in the 100-D Area and the Old Hanford Townsite springs. Concentrations of volatile organic compounds were similar to previous years with most compounds below the detection limits. Chloroform (100-B and 100-D Areas), tetrahydrofuran (100-B Area), and trichloroethylene (100-B Area) were the only volatile organic compounds detected. 


\section{Environmental Report 1996 Summary}

Water was collected from three onsite ponds located near operational areas in 1996. Although the ponds were not accessible to the public and did not constitute a direct offsite environmental impact during 1996, they were accessible to migratory waterfowl and other animals. As a result, a potential biological pathway existed for the removal and dispersal of onsite pond contaminants. With the exception of uranium-234 and uranium-238 in water samples from West Lake, radionuclide concentrations in the onsite pond water were below the DOE-derived concentration guides. The average annual total beta concentration in West Lake exceeded the ambient surface water quality criteria level.

Concentrations of most radionuclides in water collected from all three ponds during 1996 were similar to those observed during past years. However, tritium concentrations in the 1996 samples from the Fast Flux Test Facility pond were lower than those observed in 1995 . The elevated concentrations in 1995 most likely resulted from the use of a backup water supply in the 400 Area during June and July 1995. The primary source of water to the Fast Flux Test Facility pond is 400 Area sanitary water.

Irrigation water from the Riverview canal was sampled three times in 1996 to determine radionuclide concentrations. The radionuclide concentrations in offsite irrigation water were below the derived concentration guides and ambient surface water quality criteria levels.

\section{Hanford Site Drinking Water Surveillance}

Surveillance of Hanford Site drinking water was conducted to verify the quality of water supplied by site drinking water systems and to comply with regulatory requirements. Radiological monitoring was performed by the Pacific Northwest National Laboratory and DE\&S Hanford, Inc.; nonradiological monitoring was conducted by DynCorp Tri-Cities Services, Inc. These results are discussed here; nonradiological results are reported directly to the Washington State Department of Health.

During 1996, radionuclide concentrations in site drinking water were similar to those observed in recent years and were in compliance with Washington State Department of Health and EPA annual average drinking water standards.

\section{Food and Farm Product Surveillance}

The Hanford Site is situated in a large agricultural area that produces a wide variety of food products and alfalfa. Milk, vegetables, fruit, and wine were collected from areas around the site and were analyzed for cobalt-60, strontium-90, iodine-129, cesium-137, and tritium.

Most farm products sampled did not contain measurable concentrations of these radionuclides (Figure 17). lodine-129 was found at slightly elevated levels in milk samples from downwind locations. The levels were low, they have been decreasing over the past 6 years, and they are now indistinguishable between upwind and downwind locations. Tritium concentrations in wine have been reported in the past at levels higher than could be confirmed at other analytical laboratories (split samples). Recently, it was discovered that these high concentrations were caused by alcohol in the initial sample distillate; the alcohol produced spuriously high results. The problem was eliminated by removing the alcohol from the sample before analysis. 


\section{Hanford Site}

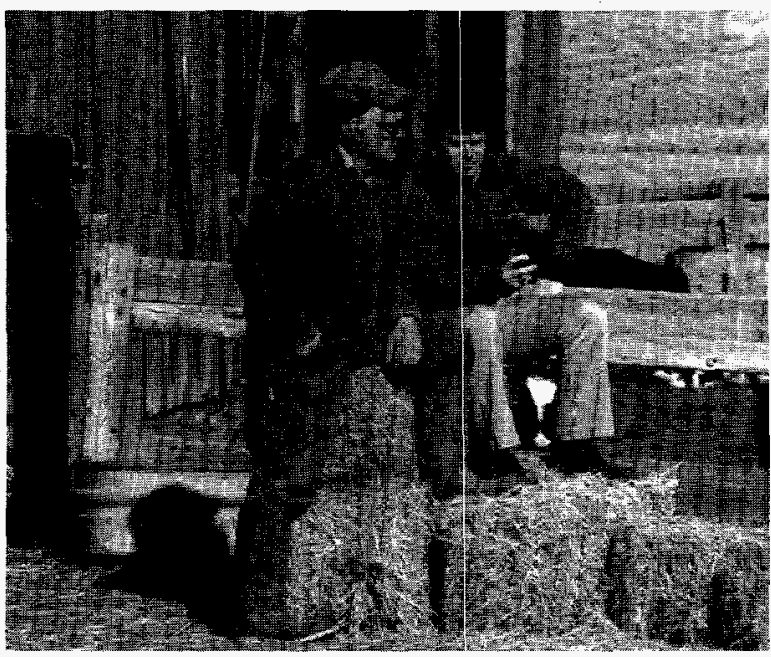

$90030246-32$

Figure 17. Food and farm products are sampled in agricultural areas surrounding the Hanford Site.

\section{Fish and Wildlife Surveillance}

Analyses of fish and wildlife samples for radionuclides in 1996 indicated that some species had accumulated radionuclides at concentrations greater than background levels. Strontium-90 was detected in the offal (i.e., carcass without most of the muscle and viscera) of Columbia River bass and carp at levels slightly exceeding those found in fish collected upstream of Hanford in the Priest Rapids Dam reservoir.

There was no apparent difference between concentrations of strontium-90 in Hanford Reach carp and background carp collected in 1996. Cesium-137 was detected in one bass fillet sample; all other fish and wildlife muscle samples did not have measurable concentrations of cesium-137. Strontium-90 was detected in all deer bone samples analyzed in 1996. Concentrations were similar to levels observed in prior years and did not indicate exposure to elevated levels of strontium in the environment. The mean concentration of strontium-90
$(0.07 \pm 0.005$ picocuries per gram, wet weight) in pheasant bone was similar to levels observed over the preceding 5 years and exceeded concentrations observed in background samples collected from 1991 through 1995 by a factor of two. Collectively, the levels of radionuclides measured in Hanford fish and wildlife indicated accumulations of small amounts of specific radionuclides that possibly originated either from historic fallout or Hanford Site activities.

\section{Soil and Vegetation Surveillance}

Soil and vegetation samples were not collected in 1996. Sampling will be conducted periodically in the future consistent with ongoing site cleanup activities.

\section{External Radiation Surveillance}

Radiological dose rates were measured at both onsite and offsite locations using thermoluminescent dosimeters. Radionuclides contributing to these measured doses were of natural and artificial origin. In 1996, terrestrial dose rates did not change significantly from those measured in 1995. The annual average background dose rate measured in distant communities was $71 \pm 1$ millirem per year compared to the 1995 average measurement of $72 \pm 8$ millirem per year (Figure 18).

The 1996 annual average perimeter dose rate was $88 \pm 10$ millirem per year; in 1995, the average measured was $86 \pm 8$ millirem per year at the same locations. All onsite dosimeters averaged $86 \pm 5$ millirem per year in 1996; in 1995 , the onsite average was $86 \pm 4$ millirem per year. Thermoluminescent dosimeters along the Columbia River shoreline had an annual average of $89 \pm 7$ millirem per year in 1996; in 1995 , the average was $103 \pm 12$ millirem per year. 


\section{Environmental Report 1996 Summary}

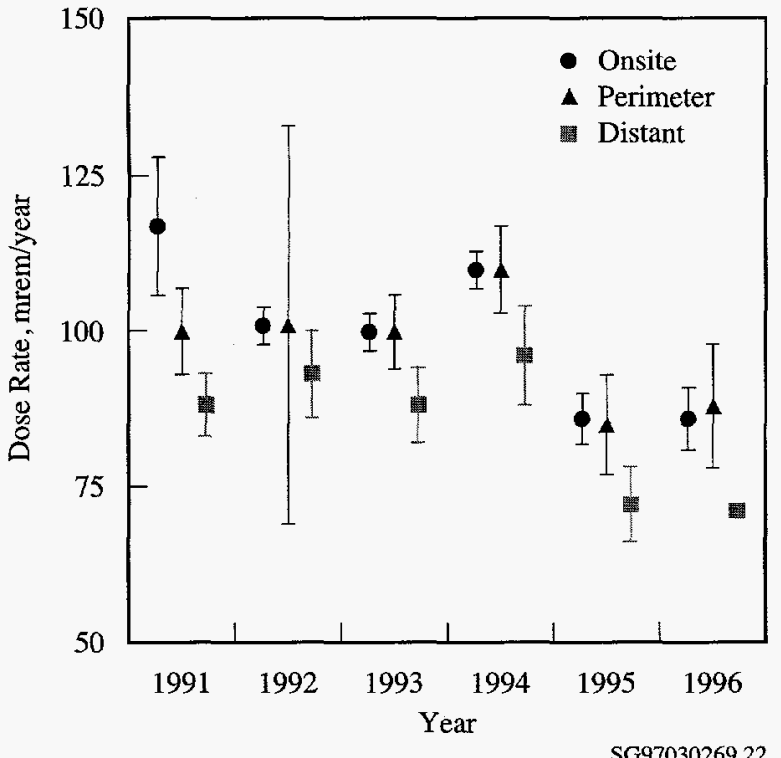

Figure 18. Average dose rates $( \pm 2$ standard error of the mean) are calculated annually. This figure compares rates from 1991 through 1996.

On average, the dose rate along the 100-N Area shoreline (129 \pm 30 millirem per year) was approximately $50 \%$ higher than the typical shoreline dose rate $(82 \pm 3$ millirem per year).

\section{Groundwater Protection and Monitoring}

Two key elements of the strategy to protect groundwater at the Hanford Site are to 1) protect the unconfined aquifer from further contamination, and 2) monitor the extent of groundwater contamination. The groundwater monitoring program at the Hanford Site documents groundwater quality to meet these needs.

The monitoring program is designed to detect new contaminant plumes and to document the distribution and movement of existing groundwater contamination (Figure 19). Monitoring provides the historical baseline for evaluating current and future risk from exposure to groundwater contamination and for deciding on remedial options. Because the geology and hydrology of the Hanford Site control the movement of contaminants in groundwater, hydrogeologic studies are an integral part of the monitoring program.

In 1996, monitoring of radiological and chemical constituents in groundwater at the Hanford Site was performed to characterize physical and chemical trends in the flow system, establish groundwater quality baselines, assess groundwater remediation, and identify new or existing groundwater problems. Groundwater monitoring was also performed to verify compliance with applicable environmental laws and regulations and to fulfill commitments made in official DOE documents.

Samples were collected from approximately 800 wells to determine the distributions of radiological and chemical constituents in Hanford Site groundwater. In addition, hydrogeologic characterization and modeling of the groundwater flow system were used to assess the monitoring network and to evaluate potential impacts of groundwater contamination.

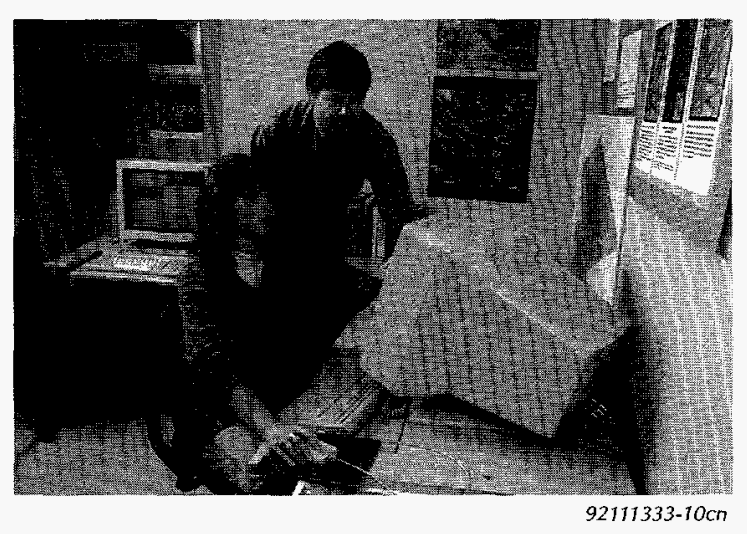

Figure 19. Scientists study groundwater flow patterns under Hanford using many years of monitoring data 


\section{Hanford Site}

During 1996, groundwater surveillance and monitoring activities were restructured into the Groundwater Monitoring Project. This project incorporates sitewide groundwater monitoring mandated by DOE Orders with near-field groundwater monitoring conducted to ensure that operations in and around specific waste disposal facilities comply with applicable regulations. Groundwater monitoring required at 26 waste treatment, storage, and disposal units is summarized below.

To assess the quality of groundwater, concentrations measured in samples were compared with the EPA drinking water stanclards and the DOEderived concentration guides. Groundwater is used for drinking at three locations on the Hanford Site. In addition, water supply wells for the city of Richland are located near the southern boundary of the Hanford Site. Radiological constituents including cobalt-60, strontium-90, technetium-99, iodine-129, cesium-137, plutonium, tritium, uranium, total alpha, and total beta were detected at levels greater than the drinking water standard in one or more onsite wells. Concentrations of strontium-90, plutonium, tritium, and uranium were detected at levels greater than the derived concentration guides.

Extensive tritium plumes extend from the 200-East and 200-West Areas into the 600 Area (Figure 20). The plume from the 200-East Area extends east and southeast, discharging to the Columbia River. This plume has impacted tritium concentrations in the 300 Area at levels of more than one-half the EPA drinking water standard. The spread of this plume farther south than the 300 Area is restricted by the groundwater flow away from the Yakima River and the recharge ponds associated with the north Richland well field. Groundwater with tritium at levels above the drinking water standard also discharges to the Columbia River at the 100-N Area.
A small but high concentration tritium plume near the 100-K East Reactor also may discharge to the river. Tritium at levels greater than the drinking water standard was also found in the 100-B, 100-D, and $100-\mathrm{F}$ Areas.

The strontium-90 plume in the 100-N Area, which contains concentrations greater than the DOEderived concentration guide, discharges to the Columbia River. Localized areas in both the 100-K and 200-East Areas also contain strontium-90 at levels greater than the derived concentration guide. Strontium-90 is found at levels greater than the EPA drinking water standard in the 100-B, 100-D, 100-F, 100-H, 100-K, and 200-West Areas and the 600 Area in the former Gable Mountain Pond area.

Technetium-99 concentrations greater than the EPA drinking water standard were found in the northwestern part of the 200-East Area and adjacent 600 Area. Technetium-99 was also detected at levels greater than the drinking water standard in the $100-\mathrm{H}$ and $200-$ West Areas and adjacent 600 Area. Groundwater in one well completed in the upper basalt-confined aquifer in the northern part of the 200-East Area had technetium-99 concentrations above the drinking water standard. Increases in technetium-99 concentrations at wells near the S-SX and T Tank Farms are being evaluated as possible indications of groundwater contamination from tank leaks.

lodine-129 was detected at levels greater than the EPA drinking water standard in the 200-East Area and in an extensive part of the 600 Area to the east and southeast. The iodine-129 and tritium plumes share common sources. lodine- 129 at levels greater than the drinking water standard also extends into the 600 Area to the northwest of the 200-East Area. lodine-129 was also found at concentrations above the drinking water standard in the southern part of 


\section{Environmental Report 1996 Summary}

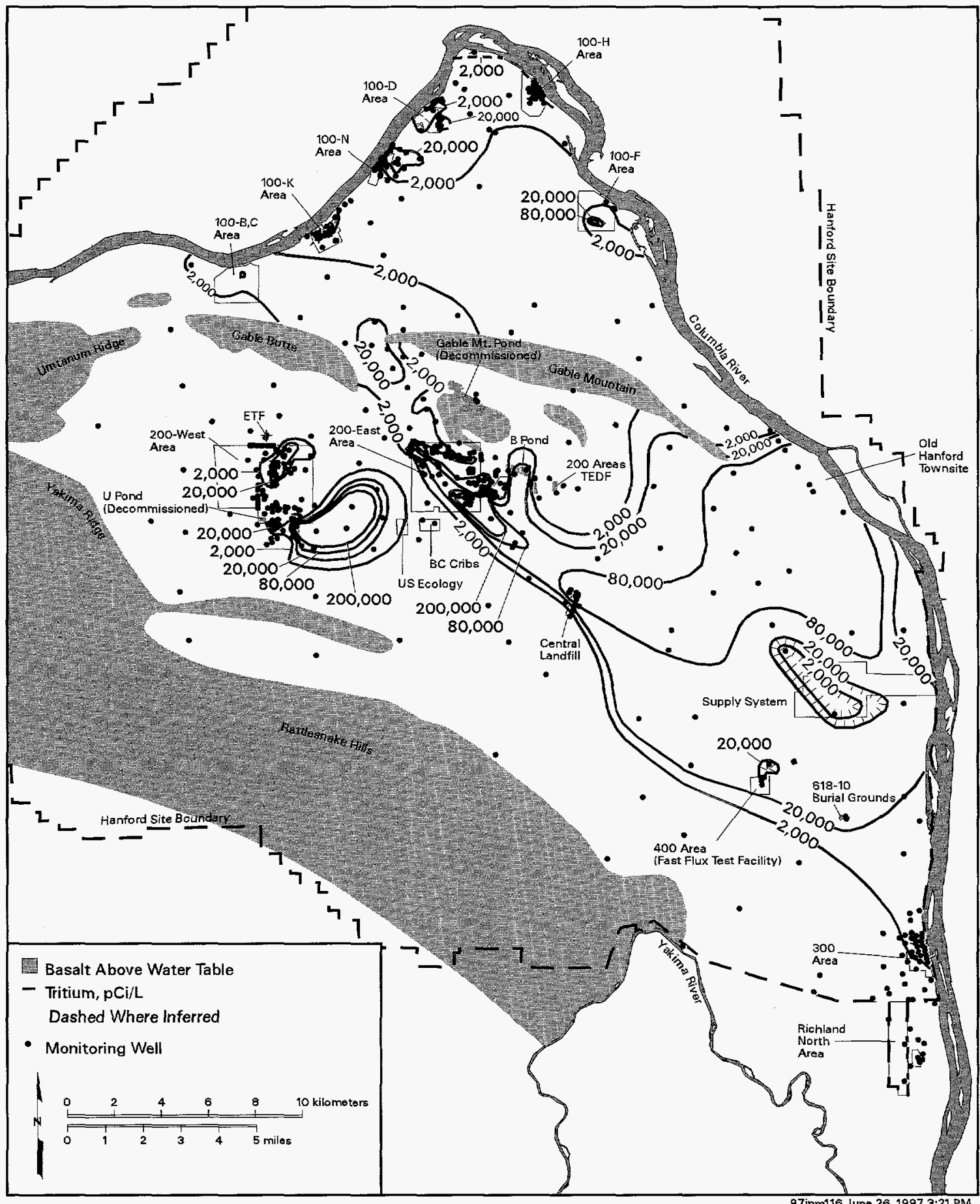

Figure 20. Extensive tritium plumes extend from the 200-East and 200-West Areas into the 600 Area. This figure shows the distribution of tritium in the unconfined aquifer, 1996. 


\section{Hanford Site}

the 200-West Area and extending into the 600 Area. There is a smaller iodine- 129 plume in the northcentral part of the 200-West Area.

Cobalt- 60 was detected above the EPA drinking water standard in the 600 Area north of the 200-East Area in one well completed in the unconfined aquifer and in one well completed in the confined aquifer. Cesium-137 was detected in one well in the 200-East Area and one well in the 200-West Area. Concentrations at the 200-East Area well were greater than the EPA drinking water standard.

Uranium was detected at levels greater than the EPA drinking water standard in wells in the 100-F, 100-H, 200-East, 200-West, 300, and 600 Areas. Groundwater with uranium concentrations greater than the drinking water stanclard appears to be discharging to the Columbia River from the 300 Area. Wells near U Plant in the 200-West Area had concentrations greater than the DOEderived concentration guide.

Plutonium was detected in groundwater samples from two wells in the 200-East Area. The level in one of these wells exceeded the DOE-derived concentration guide.

Certain nonradioactive chemicals regulated by the EPA and Washington State were also present in Hanford Site groundwater. These were carbon tetrachloride, chloroform, chromium, cyanide, fluoride, nitrate, tetrachloroethylene, and trichloroethylene.

An extensive plume of carbon tetrachloride at levels greater than the EPA drinking water standard was found in groundwater at the 200-West Area and extends into the 600 Area. A less-extensive plume of chloroform, which may be a degradation product of the carbon tetrachloride, is associated with the carbon tetrachloride plume. Maximum chloroform levels are also greater than the drinking water standard.

Chromium was found at levels greater than the EPA drinking water standard in the 100-B, 100-D, 100-F, 100-H, 100-K, 100-N, 200-East, 200-West, and 600 Areas.

Cyanide was detected above the EPA drinking water standard in one 600 Area well north of the 200-East Area.

Fluoride was measured at levels greater than the EPA primary drinking water standard in the 200-West Area.

Nitrate concentrations exceeded the EPA drinking water standard at locations in all 100 Areas, with the exception of the 100-B Area. Those plumes discharge to the Columbia River. Nitrate from the 200-East Area extends east and southeast in the same area as the tritium plume. Nitrate from sources in the northwestern part of the 200-East Area is present in the adjacent 600 Area at levels greater than the drinking water standard. Nitrate is also present at levels greater than the drinking water standard in the 200-West Area and adjoining 600 Area. Some nitrate in the 600,1100 , and north Richland areas is believed to result from offsite sources.

Tetrachloroethylene was detected at levels below the EPA drinking water standard. Trichloroethylene was found at levels greater than the EPA drinking water standard in the 100-F Area and the 600 Area. Trichloroethylene was also detected at levels greater than the drinking water standard in the 100-K, 200-West, and 300 Areas and near the Horn Rapids Landfill. 


\section{Environmental Report 1996 Summary}

\section{Potential Radiation Doses from 1996 Hanford Operations}

In 1996, potential doses to the public resulting from exposure to Hanford Site liquid and gaseous effluents were evaluated to determine compliance with pertinent regulations and limits. These doses were calculated from reported effluent releases and environmental surveillance data using Version 1.485 of the GENII computer code and Hanford-specific parameters.

The potential dose to the maximally exposed individual in 1996 from site operations was 0.007 millirem (0.00007 millisievert) compared to 0.02 millirem ( 0.0002 millisievert) calculated for 1995. The radiological dose to the population within 80 kilometers ( 50 miles) of the site, estimated to be 380,000 persons, from 1996 site operations was 0.2 person-rem (0.002 person-sievert), which is slightly less than the 1995 calculated population dose of 0.3 person-rem $(0.003$ personsievert). The average per-capita dose from 1996 site operations was 0.0005 millirem $(0.000005$ millisievert). The national average dose from background sources is 300 millirem per year ( 3 millisievert per year), and the current DOE radiological dose limit for a member of the public is $100 \mathrm{mil}$ lirem per year ( 1 millisievert per year). Therefore, the average individual potentially received $0.0005 \%$ of the DOE standard and $0.0007 \%$ of the national average background.

Special exposure scenarios not included in the dose estimates above include the ingestion of game animals residing on the site, exposure to radiation at a publicly accessible location with the maximum exposure rate, and consuming drinking water at the Fast Flux Test Facility. Doses from these scenarios would have also been small compared to the DOE dose limit. Radiological dose through the air pathway was $0.005 \%$ of the EPA limit of 10 millirem per year.

\section{Maximum “Boundary" Dose Rate}

The "boundary" radiation dose rate is the external radiation dose rate measured at publicly accessible locations on or near the site. The boundary dose rate was determined from radiation exposure measurements using thermoluminescent dosimeters at locations of expected elevated dose rates onsite and at representative locations offsite. These boundary dose rates should not be used to calculate annual doses to the general public because no one can actually reside at any of these boundary locations. However, these rates can be used to determine the dose to a specific individual who might spend some time at that location.

The dose rate at the location with the highest exposure rate along the 100- $\mathrm{N}$ shoreline (Figure 21) during 1996 was 0.02 millirem per hour $(2 \mathrm{x}$ $10^{-4}$ millisievert per hour), or about twice the average background dose rate of 0.01 millirem per hour ( $1 \times 10^{-4}$ millisievert per hour) normally observed at offsite shoreline locations. Therefore, for every hour someone spent at the 100-N Area shoreline during 1996, the external radiological dose received from Hanford operations would be approximately 0.01 millirem ( $1 \times 10^{-4}$ millisievert) above the natural background dose. If an individual spent an hour at this location, a dose would be received that is similar to the annual dose calculated for the hypothetical maximally exposed individual at Sagemoor. The public can approach the shoreline by boat but they are legally restricted from stepping 

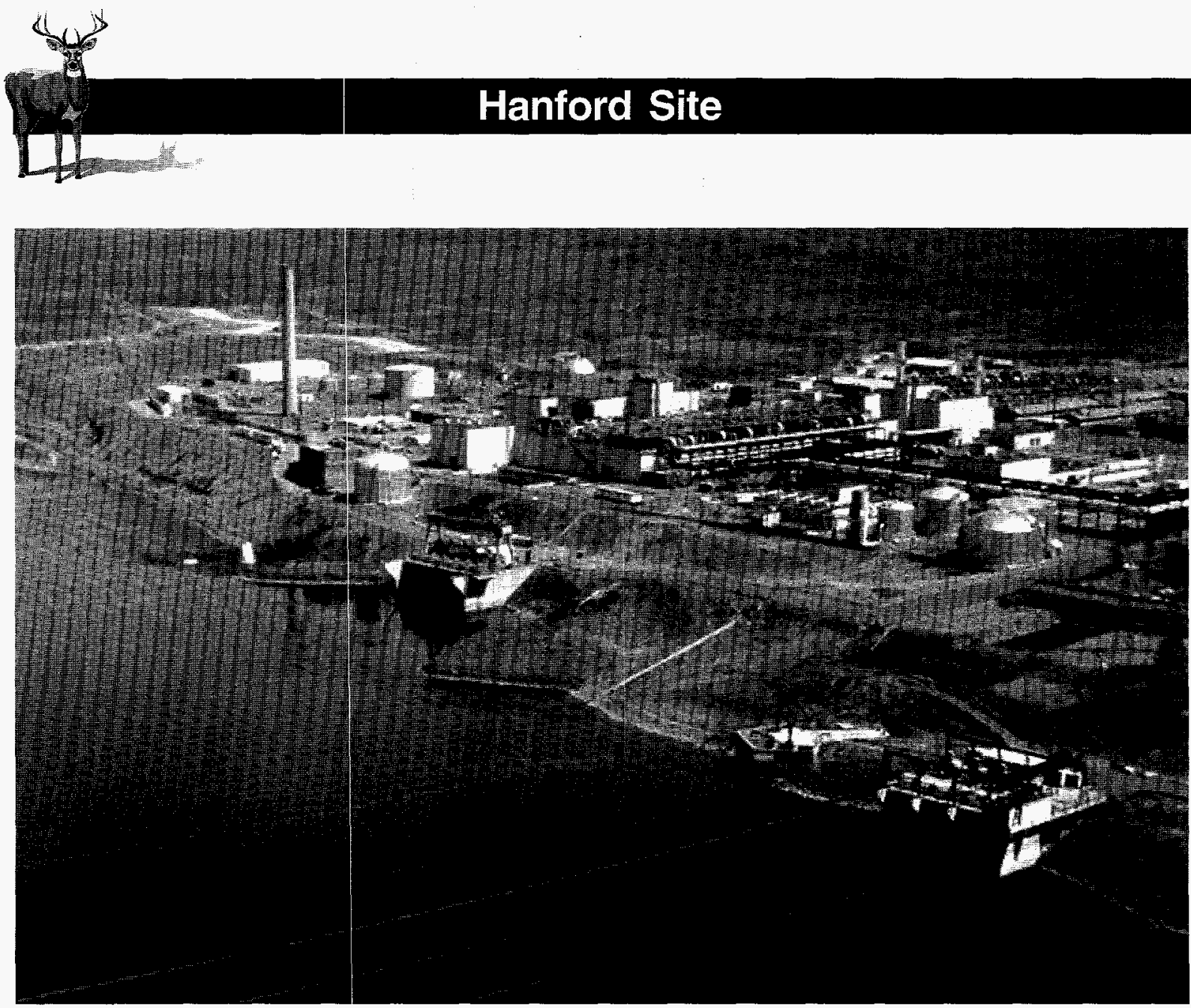

Photo from Dave Geist

Figure 21. The N Reactor complex is located along the Columbia River shoreline.

onto the shoreline. Therefore, an individual is unlikely to remain on or near the shoreline for an extended period of time.

\section{Sportsman Dose}

Wildlife have access to areas of the site that contain radioactive materials, and some do become contaminated. Sometimes contaminated wildlife travel offsite. Sampling is conducted onsite to estimate the maximum contamination levels that might possibly exist in animals hunted offsite. Because this scenario has a relatively low probability of occurring, these doses are not included in the maximally exposed individual calculation.
Listed below are estimates of the radiological doses that could have resulted if wildlife containing the maximum concentrations measured in onsite wildlife in 1996 migrated offsite, were hunted, and were eaten.

- The dose from eating 1 kilogram (2.2 pounds) of deer meat that contains the maximum concentration of cesium-137 (0.025 picocurie per gram) measured in a deer collected onsite is estimated to be $1 \times 10^{-3}$ millirem $\left(1 \times 10^{-5}\right.$ millisievert).

- The dose from eating 1 kilogram (2.2 pounds) of bass meat that contains the maximum concentrations of cesium-137 (0.02 picocurie per 


\section{Environmental Report 1996 Summary}

gram) measured in bass from the Hanford Reach of the Columbia River is estimated to be $1 \times 10^{-3}$ millirem ( $1 \times 10^{-5}$ millisievert).

- The dose from eating 1 kilogram (2.2 pounds) of pheasant meat that contains the maximum concentration of cesium-137 $(0.0047$ picocurie per gram) measured in a pheasant collected onsite is estimated to be $2 \times 10^{-4}$ millirem $\left(2 \times 10^{-6}\right.$ millisievert).

\section{Fast Flux Test Facility Drinking Water}

During 1996, groundwater was used as drinking water by workers at the Fast Flux Test Facility. Therefore, this water was sampled and analyzed throughout the year in accordance with applicable drinking water regulations. All annual average radionuclide concentrations measured during 1996 were well below applicable drinking water standards, but concentrations of tritium were detected at levels greater than typical background values. Based on the measured concentrations, the potential dose to Fast Flux Test Facility workers (an estimate derived by assuming a consumption of 1 liter per day [0.26 gallon per day] for 240 working days), the worker would receive an effective dose equivalent of $<0.2$ millirem ( $<0.002$ millisievert). The doses calculated here are well below the drinking water pathway dose limit of 4 millirem for public drinking water supplies operated by DOE.

\section{Comparison with Clean Air Act Standards}

Regulations that control radiation dose from airborne emissions from DOE facilities specify that no member of the public shall receive a dose of more than 10 millirem per year $(0.1$ millisievert per year) from exposure to airborne radionuclide effluents, other than radon, released at DOE facilities.
The 1996 air emissions from monitored Hanford facilities, including radon-220 and radon-222 releases from the 300 Area, resulted in a potential dose to a maximally exposed individual across from the 300 Area of 0.005 millirem ( $5 \times 10^{-5}$ millisievert), which represents $0.05 \%$ of the standard. Of this total, radon emissions from the 327 Building contributed 0.003 millirem ( $3 \times 10^{-5}$ millisievert); nonradon emissions from all monitored stack sources contributed 0.002 millirem ( $2 \times 10^{-5}$ millisievert). Therefore, the estimated annual dose from monitored stack releases at the Hanford Site during 1996 was well below the Clean Air Act standard.

During 1996, the estimated dose from diffuse sources to the maximally exposed individual across the river from the 300 Area was 0.03 millirem ( $3 \times 10^{-4}$ millisievert), which was greater than the estimated dose at that location from stack emissions ( 0.005 millirem or $5 \times 10^{-5}$ millisievert). Doses at other locations around the Hanford Site perimeter ranged from 0.02 to 0.06 millirem ( $2 \times 10^{-4}$ to $6 \times 10^{-4}$ millisievert). Based on these results, the combined dose from stack emissions and diffuse and unmonitored sources during 1996 was well below the EPA standard.

\section{Collective Dose to the Population Within 80 Kilometers (50 Miles)}

The average per capita dose from 1996 Hanford operations based on a population of 380,000 within 80 kilometers ( 50 miles) of the site was 0.5 microrem ( $5 \times 10^{-3}$ microsievert). To place this dose from Hanford activities into perspective, the estimate may be compared with doses from other routinely encountered sources of radiation such as natural terrestrial and cosmic background radiation, medical treatment and $x$ rays, natural radionuclides in the body, and inhalation of naturally occurring radon. The national average radiation 


\section{Hanford Site}

doses from these other sources are illustrated in Figure 22. The estimated average per capita dose to members of the public from Hanford sources is only approximately $0.0002 \%$ of the annual per capita dose (300 millirem) from natural background sources.

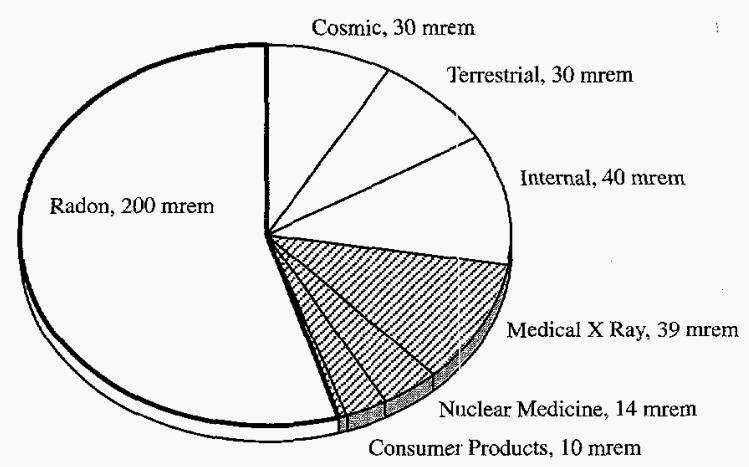

Natural, 300 mrem

07 Consumer Products and Medical, 65 mrem

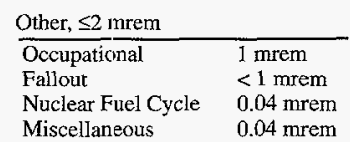

SG97030269.97

Figure 22. National annual average radiation doses from various sources (millirem).

\section{Hanford Public Radiation Dose in Perspective}

Although no increase in the incidence of health effects from low doses of radiation has been confirmed by scientists, some accept the hypothesis that low-level doses might increase the probability of cancer or other health effects. Regulatory agencies conservatively (cautiously) assume that the probability of these types of health effects at low doses (down to zero) is proportional to the probability per unit dose of these same health effects observed historically at much higher doses (in atomic bomb victims, radium dial painters).
Under these assumptions, even natural background radiation (which is hundreds of times greater than radiation from current Hanford releases) increases each person's probability or chance of developing a detrimental health effect.

Not all scientists agree on how to translate data on health effects into the numerical probability (risk) of detrimental effects from low-level radiation doses. Some studies have indicated that low doses may cause beneficial effects. Because cancer and hereditary diseases in the general population may be caused by many sources (e.g., genetic defects, sunlight, chemicals, background radiation), some scientists doubt that the risk from low-level radiation exposure can ever be conclusively proved. In developing Clean Air Act regulations, EPA uses a probability value of approximately 4 per 10 million $\left(4 \times 10^{-7}\right.$ ) for the risk of developing a fatal cancer after receiving a dose of 1 millirem (0.01 millisievert). Additional data support the reduction of even this small risk value, possibly to zero, for certain types of radiation when the dose is spread over an extended time.

Government agencies are trying to determine what level of risk is safe for members of the public exposed to pollutants from industrial activities (e.g., DOE facilities, nuclear power plants, chemical plants, and hazardous waste sites). All of these industrial activities are considered beneficial to people in some way such as providing electricity, national defense, waste disposal, and consumer products. These government agencies have a complex task in establishing environmental regulations that control levels of risk to the public without unnecessarily reducing needed benefits from industry. 


\section{Environmental Report 1996 Summary}

\section{Other Hanford Site Environmental Programs}

Environmental programs were conducted to restore environmental quality, manage waste, develop appropriate technology for cleanup activities, and study the environment. These programs briefly are discussed below.

\section{Meteorological Studies}

Meteorological measurements are taken to support site emergency preparedness, site operations, and atmospheric dispersion calculations. Weather forecasting and maintenance and distribution of climatological data are provided.

The Hanford Meteorology Station is located on the 200 Areas plateau where the prevailing wind direction is from the northwest during all months. The secondary wind direction is from the southwest. The average wind speed for 1996 was 12.9 kilometers per hour ( 8.0 miles per hour), which was 0.5 kilometer per hour ( 0.3 mile per hour) above normal; the peak gust for the year was 39 kilometers per hour (55 miles per hour). Precipitation for 1996 totaled 31.0 centimeters (12.2 inches), $195 \%$ of normal, with 146.0 centimeters (57.5 inches) of snow recorded. 1996 was the snowiest year on record. Temperatures for 1996 ranged from $-27.8^{\circ} \mathrm{C}\left(-18^{\circ} \mathrm{F}\right)$ in January and February to $42.8^{\circ} \mathrm{C}$ $\left(109^{\circ} \mathrm{F}\right)$ in August.

\section{Ecosystem Monitoring}

Wildlife and plant species inhabiting the site are monitored to determine the status and condition of populations and assess effects of site operations. Particular attention is paid to species that are rare, threatened, or endangered nationally or statewide and those of commercial, recreational, or aesthetic importance statewide or locally (Figure 23). Although no Hanford plant species have been identified from the federal list of threatened and endangered species, recent biodiversity inventory work conducted by The Nature Conservancy has identified 82 populations of 17 rare plants.

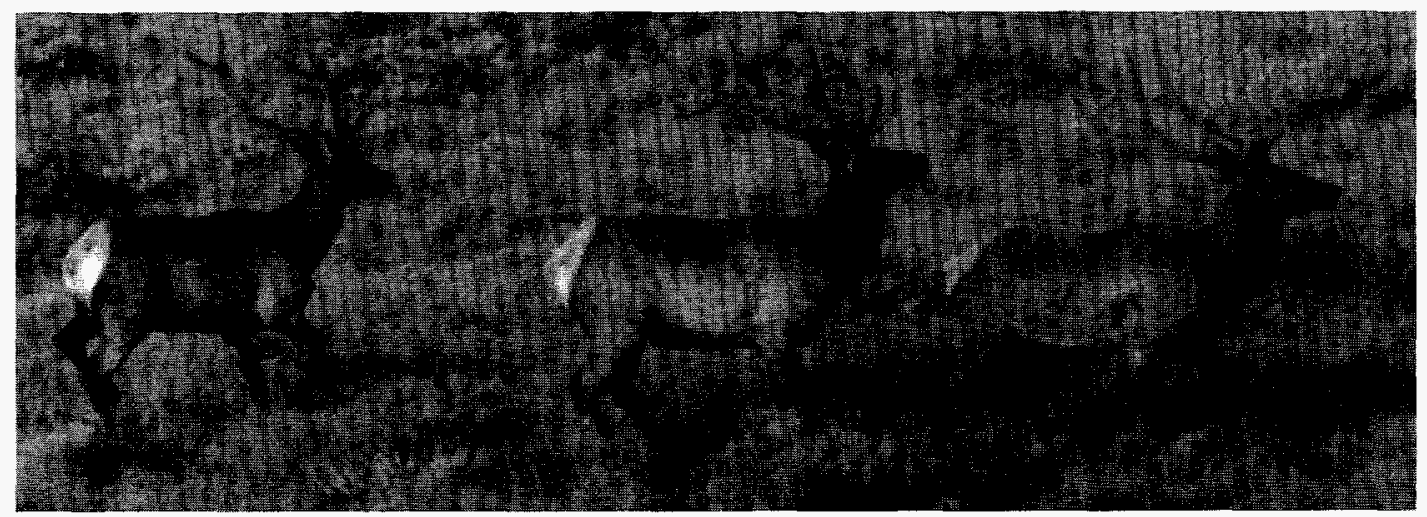

$75064-113 \mathrm{cn}$

Figure 23. The population status of Hanford wildlife-such as elk, salmon, eagles, and Canada geese-is determined annually. 


\section{Hanford Site}

The U.S. Fish and Wildlife Service lists the peregrine falcon as endangered and the bald eagle and Aleutian Canada goose as threatened. The peregrine falcon and Aleutian Canada goose are migrants through Hanford, and the bald eagle is a common winter resident and has initiated nesting on the Hanford Site but never nested successfully.

Several plant species, mammals, birds, molluscs, reptiles, and invertebrates occurring on the Hanford Site currently are candidates for formal listing under the Endangered Species Act. Fluctuations in wildlife and plant species on the Hanford Site appear to be a result of natural ecological factors and management of the Columbia River system (Figure 24).

\section{Hanford Cultural Resources Laboratory}

The DOE Richland Operations Office established a cultural resource program in 1987 that has been managed by the Hanford Cultural Resources Laboratory as part of Pacific Northwest National Labo- ratory. Cultural resources on the Hanford Site are closely monitored, and projects are relocated to avoid sites in cases where there is a possibility of altering any properties that may be eligible for listing on the National Register of Historic Places. The management of archaeological, historical, and traditional cultural resources is provided in a manner consistent with federal laws. Members of the Confederated Tribes of the Umatilla Indian Reservation, Yakama Indian Nation, Nez Perce Tribe, and Wanapum Band were actively involved in the cultural resource program during 1996.

\section{Community Involvement in Environmental Sampling}

The community-operated environmental surveillance program was initiated in 1990 to increase the public's involvement in and awareness of Hanford's surveillance program. Nine citizenoperated radiological surveillance stations were operated by local teachers at selected locations around the perimeter of the site.

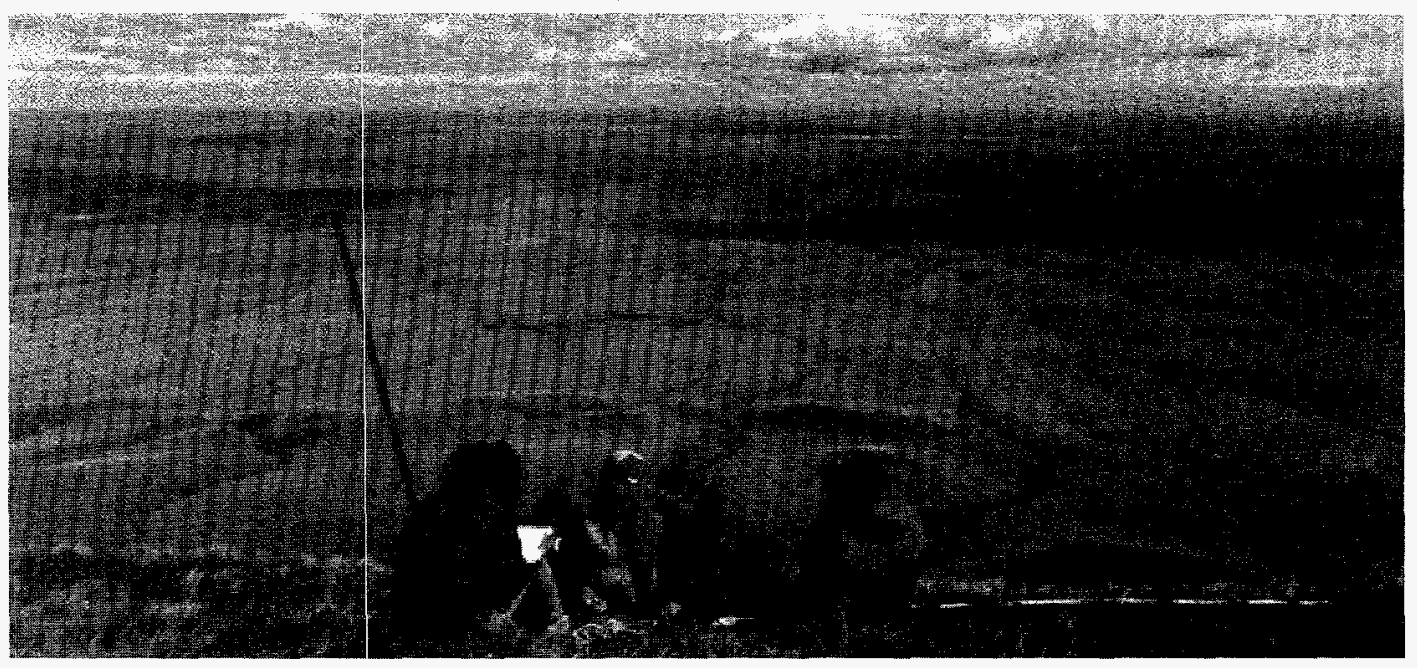

Sally Simmons photo

Figure 24. Scientists and students survey plant species and communities. 


\section{Environmental Report 1996 Summary}

\section{Quality Assurance}

Comprehensive quality assurance programs, which include various quality control practices and methods to verify data, are maintained to ensure data quality. The quality assurance programs are implemented through quality assurance plans designed to meet requirements of the American National Standards Institute/American Society of Mechanical Engineers and DOE Orders. Quality assurance plans are maintained for all activities, and auditors verify conformance.

Quality control methods include, but are not limited to, replicate sampling and analysis, analysis of field blanks and blind reference standards, participation in interlaboratory cross-check studies, and splitting samples with other laboratories.
Sample collection and laboratory analyses are conducted using documented and approved procedures. When sample results are received, they are screened for anomalous values by comparing them to recent results and historical data. Analytical laboratory performance on the submitted double-blind samples, the EPA Laboratory Intercomparison Studies Program, and the national DOE Quality Assessment Program indicated that laboratory performance was adequate overall, was excellent in some areas, and needed improvement in others. 
Hanford Site

Acknowledgments

We thank K. R. Price, Pacific Northwest National Laboratory, for providing the historical information on Hanford Site operations, and Kathy Neiderhiser for providing text processing support.

52 


\section{Can We Make This Summary More Useful for You?}

We want this summary to be easy to read and useful. To help continue this effort, please take a few minutes to let us know if the summary meets your needs. Then tear out this page, and mail or fax it to Bill Hanf, Pacific Northwest National Laboratory, P.O. Box 999, MSIN K6-75, Richland, WA 99352. Phone: (509) 376-8264; Fax: (509) 376-2210

1. How do you use the information in this summary?

$\square \quad$ To become more familiar with Hanford monitoring

- To help me make a decision about moving to the Tri-Cities

D To send to others outside the Tri-City area

T To prepare for public meetings on Hanford cleanup

$\square \quad$ Other (please explain)

2. What parts of the summary do you use?

口 Hanford Site overview/mission

$\square$ Site management

$\square$ Quality assurance

- Environmental compliance

$\square$ Regulatory oversight

$\square \quad$ Environmental monitoring

D Current issues and actions

Potential radiation doses from operations Hanford environmental programs

3. Does this guide contain

$\square \quad$ enough detail?

$\square \quad$ too much detail?

$\square \quad$ too little detail?

Comment:

4. If you could change this guide to make it more readable and useful to you, what would you change?

5. What is your affiliation?

口 Hanford Site contractor

$\square \quad$ State agency

a Public interest group

$\square$ Member of Native American Nation

a University

$\begin{array}{ll}\square & \text { DOE } \\ \square & \text { Federal agency } \\ \square & \text { Member of the public } \\ \square & \text { Local government } \\ \square & \text { Industry }\end{array}$

6. Other Comments?

Thank you! 